\title{
Influence of intermittent-upwelling on Mytilus galloprovincialis settlement patterns in the Ría de Ares-Betanzos
}

\author{
Laura G. Peteiro, Uxío Labarta*, Mª José Fernández-Reiriz, \\ X. Antón Álvarez-Salgado, Ramón Filgueira, Silvia Piedracoba
}

Consejo Superior de Investigaciones Científicas-Instituto de Investigacións Mariñas, Eduardo Cabello 6, 36208 Vigo, Spain

\begin{abstract}
Coastal upwelling systems can directly or indirectly affect the population dynamics of marine invertebrates due to their influence on residual circulation patterns and biological production cycles. In the present study we evaluated the influence of shelf winds and continental runoff on settlement patterns of Mytilus galloprovincialis at 2 contrasting locations in an embayment (Ría de Ares-Betanzos) located at the northern boundary of the Iberian-Canary current upwelling system. We quantified settlement at 2 depths $(1$ and $6 \mathrm{~m}$ ) every $15 \mathrm{~d}$ for a period of $2 \mathrm{yr}$ at an outer location (Miranda) with direct oceanic influence and at an estuarine dominated site in the inner ría (Arnela). We explored the instantaneous and delayed (15 and $30 \mathrm{~d}$ ) effects of the forcing variables to infer their influence at different times in larval development. The results showed a coupling between mussel settlement and the upwelling favourable season. Wind stress and Ekman transport along the main axis of the ría affected mussel settlement patterns significantly. Instantaneous and delayed responses showed the relevance of shelf winds at different larval developmental stages. Inverse patterns were observed between the inner and outer location in response to instantaneous winds. Onshore transport caused a decrease in settlement at Miranda, while only intense offshore transport showed a detrimental effect on settlement at Arnela. With regard to the $15 \mathrm{~d}$ delayed effect, maximum settlement abundances matched at both locations with transport values around zero. The $30 \mathrm{~d}$ delayed effect on settlement abundance showed a positive linear relationship with wind stress and Ekman transport at both locations. These relationships might be directly related to physical transport processes or indirectly associated with food availability and larval survival.
\end{abstract}

KEY WORDS: Coastal upwelling $\cdot$ Mussel $\cdot$ Settlement $\cdot$ Galician rías $\cdot$ NW Spain

\section{INTRODUCTION}

The life cycle of many benthic marine invertebrates, such as Mytilus galloprovincialis, involve a pelagic larval stage, which in some cases can last over a month (Levin \& Bridges 1995, CáceresMartínez \& Figueras 1998a, Grantham et al. 2003). During this period, multiple physical and biological processes determine the balance between mortality, dispersal and retention within parental habitats
(Eckman 1996, Pineda et al. 2009). Settlement plays a strong role in the population dynamics of complex life cycle marine invertebrates as the process linking larval and benthic stages (Connell 1985, Menge 1992).

Survival during larval development and largescale offshore oceanographic processes are usually considered main factors determining settlement abundance (Pineda et al. 2009). Thus, coastal upwelling systems have been studied recurrently 
because of their high productivity and the physical mechanisms involved in along- and cross-shore transport (Roughgarden et al. 1988, Wing et al. 1995, Shanks et al. 2000, Guisande et al. 2001, Queiroga et al. 2007, Broitman et al. 2008, Otero et al. 2008, Morgan et al. 2009a).

In eastern-boundary upwelling systems, equatorward winds transport shelf surface waters to the adjacent ocean and promote the uplifting of the cold and nutrient-rich ocean waters from 150 to $200 \mathrm{~m}$ depth to the surface, fertilizing coastal waters and enhancing phytoplankton growth. When equatorward winds relax or rotate to poleward, circulation patterns reverse producing downwelling along the coast and warm, nutrient-poor surface ocean waters occupy the shelf (Wooster et al. 1976).

Due to limited larval swimming capacity $\left(\leq 0.1 \mathrm{~cm} \mathrm{~s}^{-1}\right.$ for bivalves; Chia et al. 1984, Young 1995), upwelling systems have traditionally been considered as dispersive ecosystems, where larvae are passively transported in the surface layer: offshore during upwelling events, and onshore during downwelling episodes (Roughgarden et al. 1988, Farrell et al. 1991). Larval retention in these regions is frequently associated with local areas where coastal and bottom topography interact with upwelling/ downwelling transport events, favouring larval accumulation (Graham \& Largier 1997, McCulloch \& Shanks 2003, Mace \& Morgan 2006). However, upwelling areas have been suggested as retentive environments for some species (Poulin et al. 2002, Shanks \& Shearman 2009). Recent studies show that dispersion models assuming simple advection of larvae as inert particles overestimate larval exchange among locations (Cowen et al. 2000, Becker et al. 2007). Vertical migrations between layers flowing in opposite directions have been reported as a mechanism that enables larvae to regulate along- and cross-shore displacements (Poulin et al. 2002, Queiroga \& Blanton 2004, Shanks \& Brink 2005, Marta-Almeida et al. 2006). These mechanisms allow the maintenance of larvae close to parental habitats (Sponaugle et al. 2002) even in strong upwelling regions (Morgan et al. 2009b) and along the open coast (Shanks \& Shearman 2009, Morgan \& Fisher 2010).

The study of spatial and temporal settlement patterns is a widely accepted indirect method for inferring pre-settlement processes (Wing et al. 1995, Ladah et al. 2005, Narváez et al. 2006, Pfaff et al. 2011) despite some limitations due to differences in the temporal span of both processes (Pineda et al. 2010, Pan et al. 2011). Combined studies of settlement patterns and local oceanography are essential to infer larval dispersal patterns and potential connectivity pathways between populations (Dudas et al. 2009a). This information will help us to understand the population dynamics that would be the basis for the establishment of coastal marine reserves (Grantham et al. 2003, Mace \& Morgan 2006) and, more generally, for the development of strategies for ecosystem-based management (Leslie \& McLeod 2007). These strategies are especially important for the management of highly exploited species, such as the blue mussel in Galicia, which totals $40 \%$ of the European and $15 \%$ of the World production (Labarta 2004).

Galicia is located at the northern boundary of the Iberian-Canary current upwelling system, where upwelling-favourable northerly winds blow predominantly from March to September (Wooster et al. 1976, Arístegui et al. 2009). The upwelling season is characterized by intermittent northerly winds that relax or even reverse to southerly with frequencies from 10 to 20 d (Álvarez-Salgado et al. 1993). Coastal upwelling and downwelling episodes dictate the residual circulation patterns as well as the primary and secondary production cycles of the large coastal embayments located on the Galician coast, collectively known as 'rías' (Álvarez-Salgado et al. 2000, Figueiras et al. 2002). The typical residual circulation pattern of the rías is characterized by an outgoing surface current enriched in river water and a compensating ingoing bottom current enriched in shelf waters. This circulation pattern intensifies when northerly winds prevail and weakens when northerly winds relax, and can even reverse to an ingoing surface and an outgoing bottom current when southerly winds are predominant (Álvarez-Salgado et al. 2000). The wind-induced circulation of the rías can potentially determine larval dispersal patterns as a result of physical transport (Queiroga et al. 2007) or affect settlement abundance indirectly due to its influence on primary production and food availability during larval development (Otero et al. 2008).

The objective of the present study was to determine whether the settlement patterns of Mytilus galloprovincialis are influenced by shelf winds and continental runoff in different ways at 2 locations with different hydrographic characteristics in the Ría de Ares-Betanzos. We evaluated settlement every $15 \mathrm{~d}$ for a period of $2 \mathrm{yr}$ at an outer location (Miranda) with direct oceanic influence and at an estuarine dominated site (Arnela) in the inner ría. Preferential settlement depth was evaluated to infer larval vertical distribution according to transport mechanisms. In addition, we investigated delayed effects $(15$ and $30 \mathrm{~d}$ 
before settlement substrate deployment) of the forcing variables on settlement, to infer the relevance of these variables at different times of the planktonic life.

\section{MATERIALS AND METHODS}

\section{Study area}

The Ría de Ares-Betanzos is a complex embayment, formed by the estuaries of the Eume and Mandeo Rivers, which converge in an outer area with direct oceanic influence (Fig. 1). The surface area of the ría is $52 \mathrm{~km}^{2}$ and its total volume is $0.65 \mathrm{~km}^{3}$ (Álvarez-Salgado et al. 2011). The ría is characterized by a mesotidal and a semidiurnal tide (SánchezMata et al. 1999). Commercial mussel production is intensive in this ría ( 10 $000 \mathrm{t} \mathrm{yr}^{-1}$; Labarta 2004), but mussel cultivation farms are concentrated on the southern side of the ría (Arnela and Lorbé with 40 and 107 rafts respectively).

Between March 2006 and December 2007, larval settlement was monitored in the inner (Arnela) and

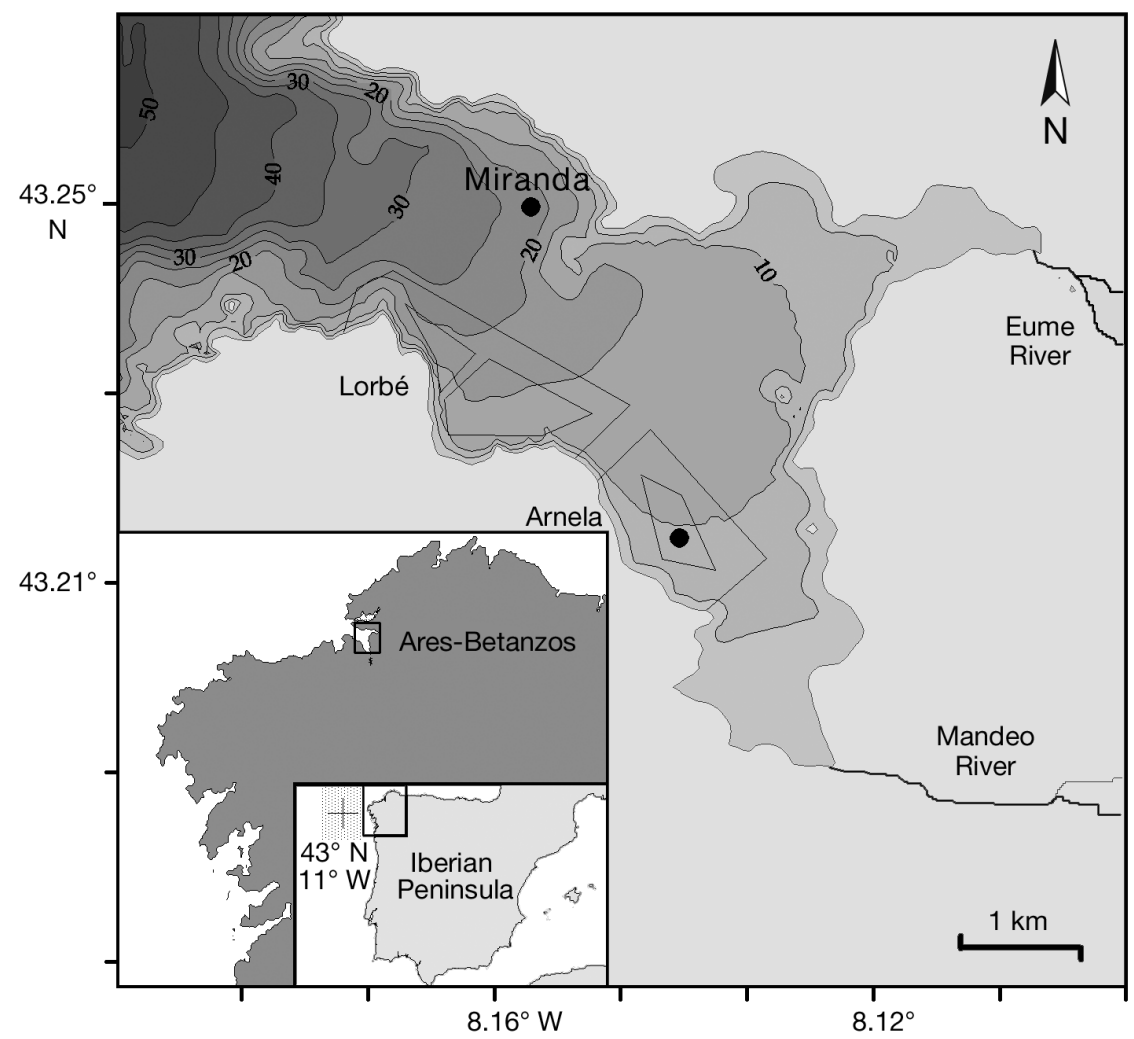

Fig. 1. The Ría de Ares-Betanzos. $(\bullet)$ = sampling stations at Arnela and Miranda; polygons $=$ commercial mussel culture areas at Arnela and Lorbé. The shaded area in the smallest inset is the $2^{\circ} \times 2^{\circ}$ cell where the geostrophic winds where calculated. Contour lines: depth (m). Modified from Álvarez-Salgado et al. (2011) outer (Miranda) Ría de Ares-Betanzos (Fig. 1). The sampling site at Arnela is located in the Mandeo River estuary area between the 5 and $10 \mathrm{~m}$ isobaths, while the sampling site at Miranda is located between the 20 and $25 \mathrm{~m}$ isobaths, in the area considered an extension of the continental shelf (Fig. 1).

\section{Larval settlement}

Settlement was monitored at each location at 1 and $6 \mathrm{~m}$ depths using 3 collecting ropes covered with jute. Prior to their deployment in the field, collecting ropes were kept for $30 \mathrm{~d}$ in seawater filtered through a $100 \mu \mathrm{m}$ mesh, renewing the water every $2 \mathrm{~d}$ to allow for the development of an adequate biofilm but preventing the occurrence of larval settlement (Porri et al. 2006). Conditioned ropes were suspended from a long-line where they remained for $15 \mathrm{~d}$ until they were sampled and replaced by new collecting ropes. Sampling consisted of the collection of 3 sub-samples of known area $(6 \times 2 \mathrm{~cm})$ from the jute covering each collecting rope (3 replicates) at both depths (1 and $6 \mathrm{~m})$. Samples were preserved in $70 \%$ ethanol until their processing in the laboratory. Sample processing consisted of the detachment of settled individuals using a $20 \%$ bleach dilution (Davies 1974), and an ultrasound bath for 5 min. Detached individuals were then sorted using a sieve kit with mesh openings between 125 and $355 \mu \mathrm{m}$, in order to facilitate their counting on a binocular microscope. The average size of individuals retained was calculated by measuring the length of the ante-posterior axis of 100 to 150 individuals for each replicate and sieve size. Individuals retained above $355 \mu \mathrm{m}$ sieve size showed a great variability in length, which prevented distinction between primary and secondary settlement (Cáceres-Martínez \& Figueras 1998a). Therefore settlement magnitude (S) was calculated as the number of settlers on a $<355 \mu \mathrm{m}$ sieve per collector (ind. $\mathrm{col}^{-1}$ ).

Settlement synchrony among locations and depths was assessed through cross-correlation $\left(\rho_{\mathrm{xy}}(j)\right)$. Given the autocorrelation structure of the time series, the significance of cross- 
correlations was assessed based on $95 \%$ CI calculated for the 'effective' df $\left(N^{*}\right.$; Pyper \& Peterman 1998), estimated through the equation:

$$
\frac{1}{N^{*}}=\frac{1}{N}+\frac{2}{N} \sum_{j=1}^{\infty} \frac{(N-j)}{N} \rho_{\mathrm{xx}}(j) \cdot \rho_{\mathrm{yy}}(j)
$$

where $N$ is size of the time series and $\rho_{\mathrm{Xx}}(j), \rho_{\mathrm{yy}}(j)$ are autocorrelation coefficients of settlement in locations $x$ and $y$ for a delay $j$.

Cumulative settlement per year was calculated as the sum of the annual counts per replicate (collector rope) to estimate average and standard deviation (SD) at each location and depth. A factorial repeated measures ANOVA was performed to assess the effect of the factors location (Arnela and Miranda), depth ( 1 and $6 \mathrm{~m}$ ) and year (2006 and 2007) on the accumulated settlement. Fisher's LSD test was used as a post-hoc test.

\section{Environmental variables}

Continental runoff to the Ría de Ares-Betanzos is mostly a combination of the discharges of rivers Eume and Mandeo (Fig. 1). The flow at the mouth of the Mandeo River (with a total drainage basin of $456.97 \mathrm{~km}^{2}$ ) was estimated from the volume at the nearby gauge station of Irixoa (that controls $248.21 \mathrm{~km}^{2}$ of the drainage basin) provided by Augas de Galicia (Galician Government), by applying Horton's proportional law (Strahler 1963). The volume of the Eume River is a combination of regulated and natural flows. Daily volumes of the Eume reservoir, which regulates $376.20 \mathrm{~km}^{2}$ ( $80 \%$ of the drainage basin), were provided by ENDESA S.A., the company in charge of its management. The natural component of the Eume River flow was estimated from the flow of the Mandeo River by again applying Horton's Law, considering that the drainage basin not regulated by the reservoir is only $94.04 \mathrm{~km}^{2}$. Daily continental runoff to the Ría de Ares-Betanzos $\left(\mathrm{Q}_{\mathrm{R}_{i}} \mathrm{~m}^{3} \mathrm{~s}^{-1}\right)$ was calculated as the sum of the Eume and Mandeo flows.

Wind stress $\left(\tau_{\mathrm{x}}, \tau_{\mathrm{y}}\right)$ and Ekman transport $\left(-\mathrm{Q}_{\mathrm{x}}, \mathrm{Q}_{\mathrm{y}}\right)$ due to regional shelf winds were roughly estimated from wind speed and direction according to the methodology described by Bakun (1973) adapted for the Iberian Peninsula by Lavín et al. (1991):

$$
\begin{array}{ll}
\tau_{\mathrm{x}}=\rho_{\mathrm{A}} \cdot \mathrm{C}_{\mathrm{D}} \cdot|\mathrm{V}| \cdot \mathrm{V}_{\mathrm{x}} & \tau_{\mathrm{y}}=\rho_{\mathrm{A}} \cdot \mathrm{C}_{\mathrm{D}} \cdot|\mathrm{V}| \cdot \mathrm{V}_{\mathrm{y}} \\
-\mathrm{Q}_{\mathrm{x}}=-\frac{\tau_{\mathrm{y}}}{\rho_{\mathrm{W}} \cdot f} & \mathrm{Q}_{\mathrm{y}}=\frac{\tau_{\mathrm{x}}}{\rho_{\mathrm{W}} \cdot f}
\end{array}
$$

where $\rho_{\mathrm{A}}$ is air density $\left(1.22 \mathrm{~kg} \mathrm{~m}^{-3}\right.$ at $\left.15^{\circ} \mathrm{C}\right), \mathrm{C}_{\mathrm{D}}$ is an empirical dimensionless drag coefficient $\left(1.4 \times 10^{-3}\right)$, $f$ is the Coriolis parameter $\left(9.946 \times 10^{-5} \mathrm{~s}^{-1}\right.$ at $43^{\circ}$ latitude), $\rho_{\mathrm{W}}$ is sea water density $\left(\sim 1025 \mathrm{~kg} \mathrm{~m}^{-3}\right),|\mathrm{V}|, \mathrm{V}_{\mathrm{x}}$ and $\mathrm{V}_{\mathrm{y}}$ are the average daily modules, westerly and southerly components of the geostrophic wind in a $2^{\circ} \times 2^{\circ}$ cell centred at $43^{\circ} \mathrm{N}, 11^{\circ} \mathrm{W}$, representative of the study area. Average daily winds were estimated from atmospheric surface pressure charts, provided at $6 \mathrm{~h}$ intervals by the Spanish Institute of Meteorology.

$\tau_{\mathrm{x}}, \tau_{\mathrm{y}}$ were rotated $30^{\circ}$ clockwise to produce longitudinal $\left(\tau_{\mathrm{L}}\right)$ and transversal $\left(\tau_{\mathrm{T}}\right)$ components of the wind stress to the main axis of the Ría de Ares-Betanzos (Fig. 1). Longitudinal $\left(-\mathrm{Q}_{\mathrm{L}}\right)$ and transversal $\left(\mathrm{Q}_{\mathrm{T}}\right)$ components of the Ekman transport were also obtained from $\tau_{\mathrm{T}}$ and $\tau_{\mathrm{L}}$ respectively. Positive values of $-\mathrm{Q}_{\mathrm{L}}$ indicate an offshore Ekman transport and negative values an onshore Ekman transport, while positive and negative values of $\mathrm{Q}_{\mathrm{T}}$ indicate displacement of the surface layer towards NE and SW respectively. Given that $-\mathrm{Q}_{\mathrm{L}}$ is proportional to $\tau_{\mathrm{T}}$ and $\mathrm{Q}_{\mathrm{T}}$ is proportional to $\tau_{\mathrm{L}}$, only $-\mathrm{Q}_{\mathrm{L}}$ and $\mathrm{Q}_{\mathrm{T}}$ will be used as explanatory variables. Therefore, $-\mathrm{Q}_{\mathrm{L}}$ will be a proxy to both the effect of a transversal wind stress and a longitudinal Ekman transport and $\mathrm{Q}_{\mathrm{T}}$ a proxy to the effect of a longitudinal wind stress and a transversal Ekman transport.

Daily values of $\mathrm{Q}_{\mathrm{R}},-\mathrm{Q}_{\mathrm{L}}$ and $\mathrm{Q}_{\mathrm{T}}$ were condensed to $15 \mathrm{~d}$ averages to match settlement sampling frequency $(15 \mathrm{~d})$. Seasonal patterns in these environmental variables were analyzed by means of general additive models (GAMs), as implemented in the mgcv library of R (R Development Core Team 2010).

GAMs allow the exploration of non-linear functional relationships between dependent and explanatory variables, fitting predictor variables by smooth functions (Guisan et al. 2002). The general model form of a GAM is:

$$
\mathrm{E}(Y)=\alpha+\sum_{j=1}^{p} f_{j}\left(\mathrm{X}_{j}\right)+\varepsilon
$$

where $\mathrm{E}(Y)$ is the estimated value of the response variable, $\alpha$ is the population intercept, $X_{j}$ are the covariates and $f_{j}$ are the smooth unknown functions estimated for each covariate (Wood 2006).

To test the influence of the environmental variables $\left(Q_{R},-Q_{L}\right.$ and $Q_{T}$ ), seasonal cycles (day of the year) and depth on settlement GAMs were built. Depth was included as a factor (1 and $6 \mathrm{~m})$. Continuous variables were considered as smoothed terms in the model and estimated with thin plate regression splines. Settlement data were characterized by many zero-valued observations and a long right tail. Zero-inflated data is a common feature in species abundance studies, which prevents the use of com- 

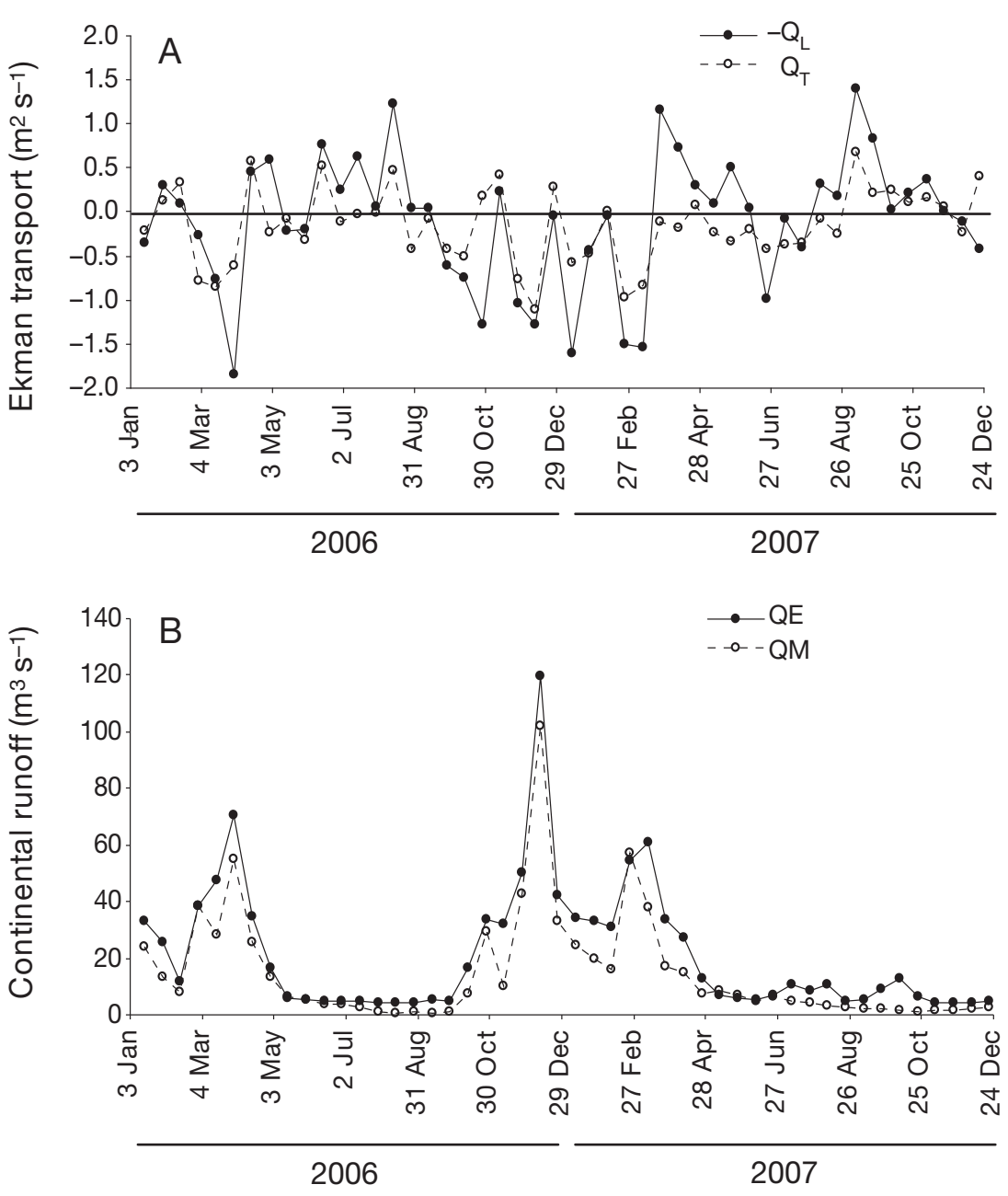

Fig. 2. Time series of (A) Ekman transport longitudinal $\left(-Q_{L}\right)$ and transversal $\left(\mathrm{Q}_{\mathrm{T}}\right)$ to the main axis of the ría and (B) continental runoff of rivers Eume (QE) and Mandeo (QM) during years 2006 and 2007 in the Ría de Ares-Betanzos

The model selection protocol was repeated using explicative variables lagged by 1 and 2 sampling intervals, in order to investigate delayed effects of the forcing variables on settlement. The instantaneous response (lag 0) and time-lagged response (lag 1 and 2 sampling intervals) models were compared by percentage of variability explained and their BICs, to select the most explicative effects on settlement magnitude.

\section{RESULTS}

\section{Environmental parameters}

Fig. 2A shows the time series of the fortnightly-averaged Ekman transport longitudinal and transversal to the main axis of the ría $\left(-\mathrm{Q}_{\mathrm{L}}\right.$ and $\left.\mathrm{Q}_{\mathrm{T}}\right)$. Seasonality explained $15.3 \%$ of the total variance of $-Q_{L}$, defining an upwelling-favourable season $\left(-\mathrm{Q}_{\mathrm{L}}>0\right)$ between day of the year 100 and 300 (April 9th and October 26th), and a downwelling-favourable season $\left(-\mathrm{Q}_{\mathrm{L}}\right.$ $<0$ ) for the rest of the year (Fig. 3A). There were no significant differences (Student's $t$-test, $\mathrm{p}=0.109$ ) between the average $( \pm S D)-Q_{L}$ values for the upwelling seasons of $2006(0.07 \pm 1.09$ $\left.\mathrm{m}^{2} \mathrm{~s}^{-1}\right)$ and $2007\left(0.20 \pm 0.94 \mathrm{~m}^{2} \mathrm{~s}^{-1}\right)$. In addition, the coefficient of variation of $-\mathrm{Q}_{\mathrm{L}}$ (Fig. 2A) was larger for the

mon assumptions on data distribution for modelling (Barry \& Welsh 2002). Therefore, data were modelled in 2 steps; first the association between the presence and absence of settlement and the available covariates was modelled and second the relationship between abundance and the covariates, conditionally on the presence of the organism, was modelled (Barry \& Welsh 2002). The presenceabsence data were modelled using a binomial distribution with a logit-link. Over-dispersion on settlement abundance data was accounted for using a negative binomial distribution with a log-link function. Bayesian's information criterion (BIC) was used to select the optimal set of variables for inclusion in the models. Model validation included the verification of homogeneity, normality and independence assumptions (Zuur et al. 2009). upwelling season of $2006(1600 \%)$ than for 2007 $(480 \%)$. The parallel time course of the fortnightaverage longitudinal and transversal components of the Ekman transport (Fig. 2A) does not allow differentiation between the effect of the longitudinal wind stress (proportional to $\mathrm{Q}_{\mathrm{T}}$ ) and the longitudinal Ekman transport $\left(-\mathrm{Q}_{\mathrm{L}}\right)$ on the residual circulation of the ría.

River discharge showed a marked seasonal pattern that explained $38.0 \%$ of total variance (Figs. 2B \& 3B). The pattern of $\mathrm{Q}_{\mathrm{R}}$ was opposite to that of $-Q_{L}$, showing minimum values during the upwelling-favourable season (Fig. 3). Continental runoff was significantly higher (Student's $t$-test, $\mathrm{p}<0.005$ ) and more variable in 2006 (average \pm $\mathrm{SD}=15.81 \pm 20.15 \mathrm{~m}^{3} \mathrm{~s}^{-1}$ ) than in 2007 (12.59 \pm $\left.5.98 \mathrm{~m}^{3} \mathrm{~s}^{-1}\right)$. 

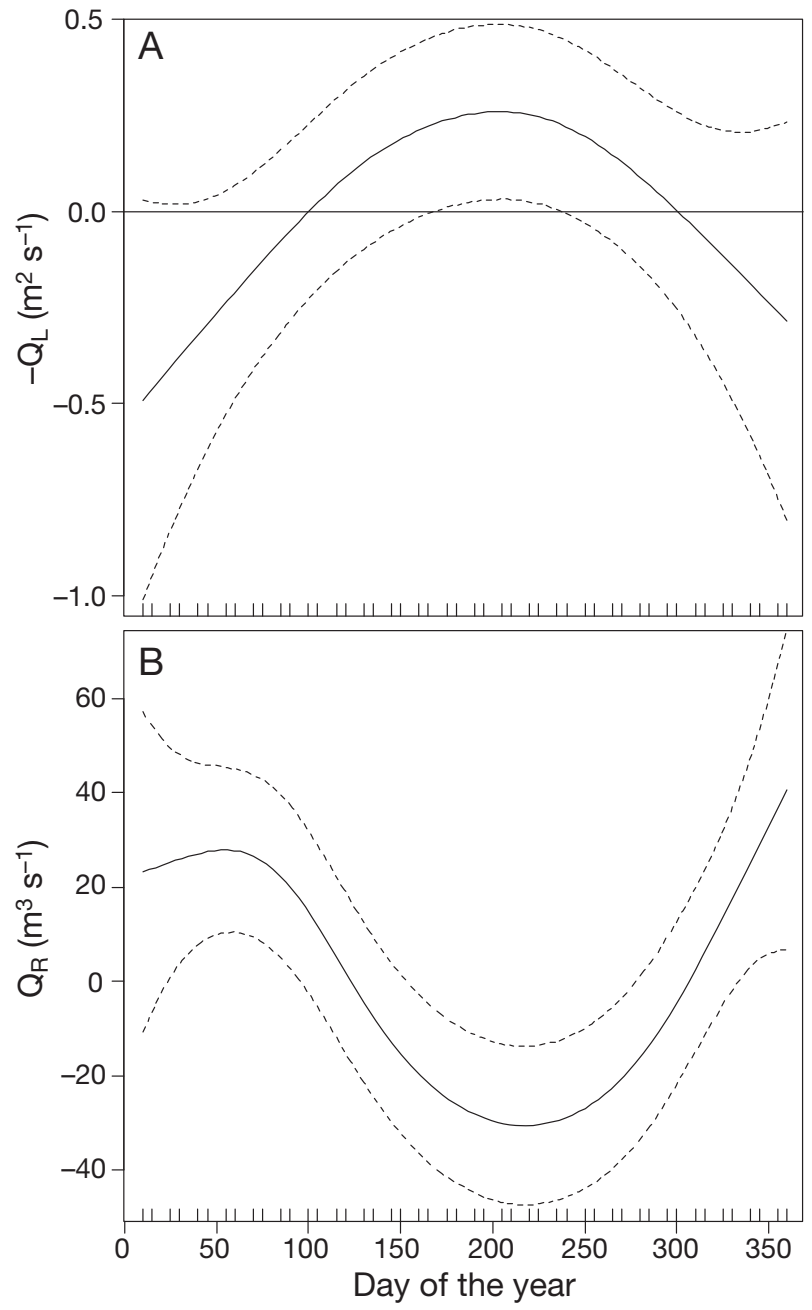

Fig. 3. Seasonal patterns of environmental variables. Results of general additive models showing the effect of variable 'Day of year' on (A) longitudinal component of Ekman transport $\left(-\mathrm{Q}_{\mathrm{L}}\right)$ and $(\mathrm{B})$ continental runoff $\left(\mathrm{Q}_{\mathrm{R}}\right)$. Dashed lines show $95 \% \mathrm{CI}$, and tick marks along the $\mathrm{x}$-axis below each curve represent effect values where observations occurred

\section{Settlement patterns}

Settlement abundance showed a similar seasonal pattern in 2006 and 2007, characterized by an initial major peak followed by 2 to 4 peaks of smaller amplitude during the upwelling-favourable season and absence or residual settlement during the rest of the year (Fig. 4). The regression model for settlement presence-absence supported the strong seasonal component of settlement (Table 1, Fig. 5). Seasonality explained $64.1 \%$ of the total deviance. Only the inclusion of the factor depth, which showed a settlement probability reduction of 0.18 at $6 \mathrm{~m}$, improved the fit ( $67 \%$ of deviance explained).

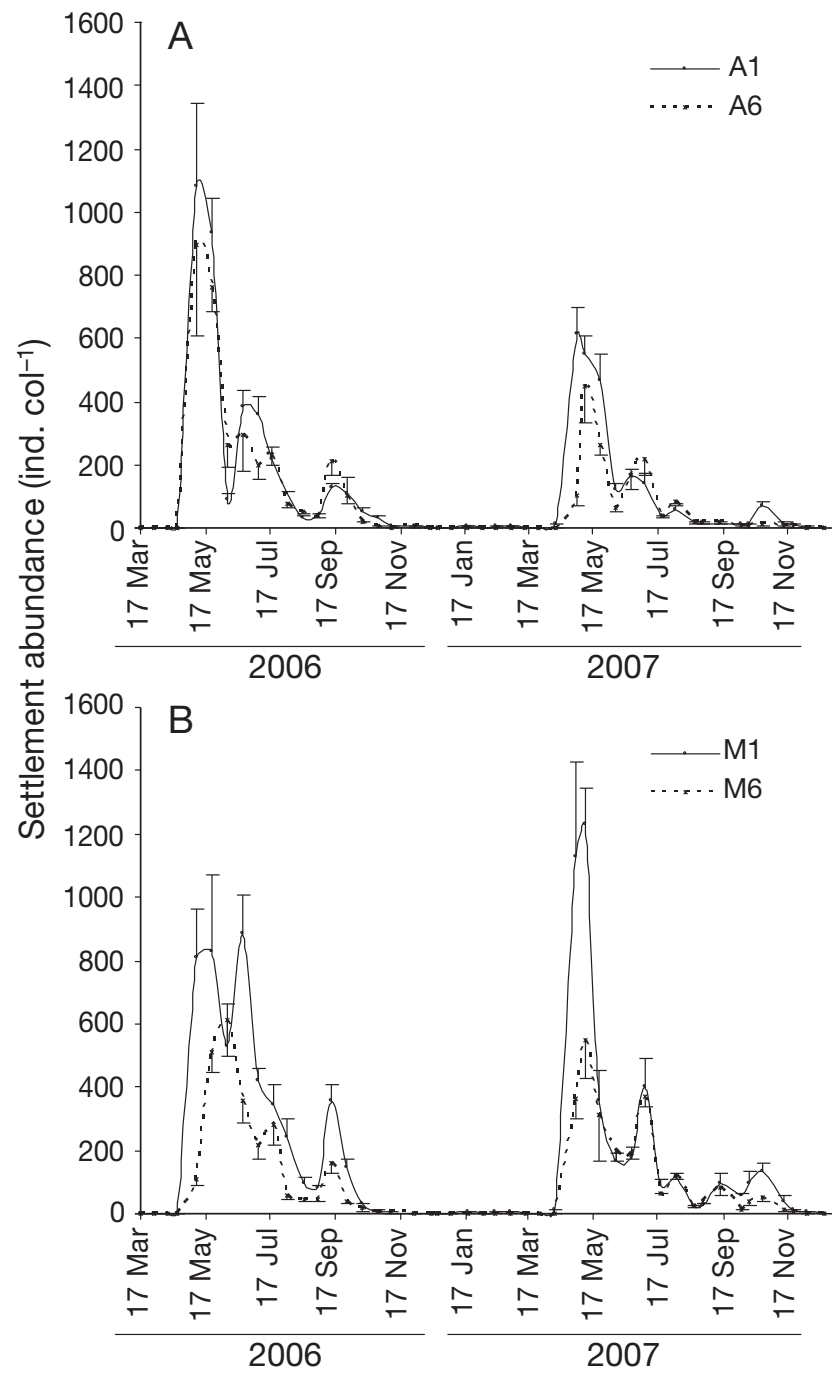

Fig. 4. Mytilus galloprovincialis. Average settlement abundance (ind. collector ${ }^{-1}$ ) and SD in locations (A) Arnela at 1 and $6 \mathrm{~m}$ depth (A1 and A6) and (B) Miranda at 1 and $6 \mathrm{~m}$ depth (M1 and M6) during 2006 and 2007

Maximum cross-correlation coefficients between locations showed settlement synchrony ( $r \geq 0.77$ for lag 0 ; Table 2) except in the case of Miranda at $6 \mathrm{~m}$ depth, which showed higher correlations at lag -1 , indicating some delay in settlement (Table 2).

The repeated measures ANOVA showed significantly higher settlement abundances in the outermost location, Miranda (Tables $3 \& 4$ ). Differences in settlement magnitude between years were detected only at Arnela, with a significant decrease in settlement during 2007 (Tables 3 \& 4). Both locations showed higher settlement at $1 \mathrm{~m}$ depth, but the significant interaction between depth and location revealed greater differences 
Table 1. Mytilus galloprovincialis. Structure of the model selected to describe settlement presence-absence. The inverse of the logit function has been applied to get the estimated values and SE on the scale of actual probability. edf: estimated degrees of freedom

\begin{tabular}{|c|c|c|c|c|}
\hline \multicolumn{5}{|c|}{ Parametric coefficients } \\
\hline Parameter & Estimate & $\mathrm{SE}$ & $Z$ & $\mathrm{p}$ \\
\hline Depth: $6 \mathrm{~m}$ & -0.184 & 0.066 & -3.803 & 0.0001 \\
\hline \multicolumn{5}{|c|}{ Smooth terms (non-parametric) } \\
\hline Parameter & edf & $\chi^{2}$ & \multicolumn{2}{|l|}{$\mathrm{p}$} \\
\hline Date & 1.975 & 101.9 & \multicolumn{2}{|l|}{$<2 \times 10^{-16}$} \\
\hline \multicolumn{2}{|c|}{$\mathrm{R}^{2}$ adjusted: 0.661} & \multicolumn{3}{|c|}{$\%$ Deviance explained. $67.0 \%$} \\
\hline
\end{tabular}

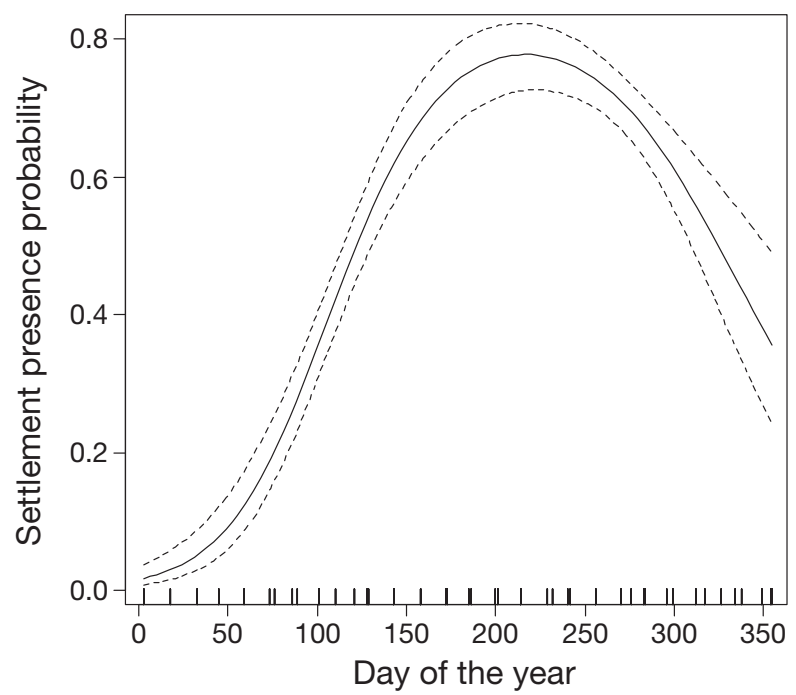

Fig. 5. Mytilus galloprovincialis. Results of the generalized additive models showing the partial effect of the variable 'day of the year' on settlement presence probability. Dashed lines show $95 \% \mathrm{CI}$, and tick marks along the $x$-axis below the curve represent effect values where observations occurred

in settlement density between depths at Miranda (Tables $3 \& 4$ ).

Regression models for settlement abundance were performed for each sampling site because of the interactions detected by the ANOVA analysis (Table 4). They showed a strong seasonal pattern in settlement abundances in both locations $(77.7 \%$ and $76.4 \%$ of the total variability explained at Arnela and Miranda, respectively; Table 5). The inclusion of the factor depth in the model decreased BIC values and increased the variance explained at both study areas, but again a greater increase in the amount of variance explained was observed at Miranda (Tables $5 \& 6$ ). None of the
Table 2. Mytilus galloprovincialis. Cross-correlation coefficients showing settlement synchrony and delays between locations and depths of study (Arnela and Miranda at 1 and $6 \mathrm{~m}$ depth; A1, A6, M1 and M6, respectively). Only the significant correlation coefficients are detailed. The specific lag for each coefficient is given in brackets

\begin{tabular}{|c|c|c|c|}
\hline & A1 & A6 & M1 \\
\hline A6 & $\begin{array}{l}0.59(\operatorname{lag}-1) \\
0.93(\operatorname{lag} 0)\end{array}$ & & \\
\hline M1 & $\begin{array}{l}0.54(\operatorname{lag}-1) \\
0.85(\log 0) \\
0.51(\log +1)\end{array}$ & $\begin{array}{l}0.77(\operatorname{lag} 0) \\
0.53(\operatorname{lag}+1)\end{array}$ & \\
\hline M6 & $\begin{array}{l}0.56(\operatorname{lag}-2) \\
0.81(\operatorname{lag}-1) \\
0.64(\log 0)\end{array}$ & $\begin{array}{l}0.53(\operatorname{lag}-2) \\
0.74(\operatorname{lag}-1) \\
0.67(\operatorname{lag} 0)\end{array}$ & $\begin{array}{l}0.76(\operatorname{lag}-1) \\
0.85(\operatorname{lag} 0) \\
0.51(\operatorname{lag}+1)\end{array}$ \\
\hline
\end{tabular}

Table 3. Mytilus galloprovincialis. Accumulated settlement (average \pm SD) (ind. collector ${ }^{-1}$ ) through 2006 and 2007 in each study location and depth

\begin{tabular}{|lccc|}
\hline Site & Depth $(\mathrm{m})$ & 2006 & 2007 \\
\hline Arnela & 1 & $3582.0 \pm 303.7$ & $2365.7 \pm 133.2$ \\
& 6 & $3154.3 \pm 375.5$ & $1478.7 \pm 175.6$ \\
Miranda & 1 & $4784.7 \pm 339.9$ & $4182.0 \pm 380.1$ \\
& 6 & $2594.0 \pm 116.9$ & $2309.3 \pm 250.4$ \\
\hline
\end{tabular}

Table 4. Mytilus galloprovincialis. Repeated measures ANOVA assessing the effect of factors Location (Loc; Arnela and Miranda), Depth (1 and $6 \mathrm{~m}$ ) and Year (2006 and 2007) on accumulated settlement magnitude (ind. collector ${ }^{-1}$ )

\begin{tabular}{|lcccc|}
\hline \multirow{2}{*}{ Model } & \multicolumn{4}{c|}{ Accumulated settlement } \\
& df & SS & $F$ & $p$ \\
\hline Loc & 1 & 4057393 & 70.39 & $<0.001$ \\
Depth & 1 & 10846081 & 252.77 & $<0.001$ \\
Year & 1 & 4627060 & 47.59 & $<0.01$ \\
Loc $\times$ Depth & 1 & 2833188 & 66.03 & $<0.01$ \\
Loc $\times$ Year & 1 & 1934608 & 19.90 & $<0.05$ \\
Year $\times$ Depth & 1 & 5891 & 0.053 & 0.829 \\
Loc $\times$ Year $\times$ Depth & 1 & 408726 & 3.671 & 0.128 \\
& & & & \\
\hline
\end{tabular}

models revealed a significant relationship between continental runoff and settlement density using instantaneous (lag 0) or lagged responses (lag 1 and 2 sampling periods). The longitudinal and transversal components of the Ekman transport to the main axis of the ría both showed a significant effect on settlement abundances for instantaneous and lagged responses, similar percentages of variance explained, BIC values (Table 5) and analogous partial effects on settlement abundance. As 
Table 5. Mytilus galloprovincialis. Percentage of deviance explained and Bayesian's information criterion (BIC) values from step-wise model selection to describe settlement abundance in both study locations, assessing instantaneous (lag 0) and time-lagged effects (lag 1 and lag 2) of both Ekman transport components $\left(-\mathrm{Q}_{\mathrm{L}}\right.$ and $\left.\mathrm{Q}_{\mathrm{T}}\right)$ using generalized additive models. dev. expl. = deviance explained

\begin{tabular}{|c|c|c|c|c|}
\hline \multirow[b]{2}{*}{ Model } & \multicolumn{2}{|c|}{ Arnela } & \multicolumn{2}{|c|}{ Miranda } \\
\hline & $\begin{array}{c}\% \text { dev. } \\
\text { expl. }\end{array}$ & $\mathrm{BIC}$ & $\begin{array}{c}\% \text { dev. } \\
\text { expl. }\end{array}$ & BIC \\
\hline Date & 77.7 & 2200.5 & 76.4 & 2351.7 \\
\hline Date + Depth & 78.5 & 2198.2 & 80.0 & 2320.8 \\
\hline Date + Depth $+-\mathrm{Q}_{\mathrm{L}-\text { lag0 }}$ & 82.3 & 2182.4 & 83.3 & 2296.6 \\
\hline Date + Depth $+Q_{\text {T-lag0 }}$ & 83.5 & 2178.6 & 83.2 & 2302.2 \\
\hline Date + Depth $+-\mathrm{Q}_{\mathrm{L}-\text { lag } 0}+\mathrm{Q}_{\mathrm{T} \text {-lag0 }}$ & 83.6 & 2193.1 & 84.5 & 2301.6 \\
\hline Date + Depth $+-\mathrm{Q}_{\mathrm{L}-\text { lag1 }}$ & 89.4 & 2119.4 & 93.2 & 2211.5 \\
\hline Date + Depth $+Q_{\text {T-lag1 }}$ & 88.1 & 2144.5 & 92.5 & 2228.9 \\
\hline Date + Depth $+-\mathrm{Q}_{\mathrm{L}-\mathrm{lag} 1}+\mathrm{Q}_{\mathrm{T}-\mathrm{lag} 1}$ & 89.9 & 2126.5 & 82.2 & 2317.0 \\
\hline Date + Depth $+-\mathrm{Q}_{\mathrm{L}-\text { lag2 }}$ & 81.8 & 2171.7 & 86.2 & 2253.7 \\
\hline Date + Depth $+\mathrm{Q}_{\text {T-lag2 }}$ & 82.5 & 2163.5 & 83.9 & 2282.7 \\
\hline Date + Depth $+-\mathrm{Q}_{\mathrm{L}-\text { lag2 }}+\mathrm{Q}_{\mathrm{T} \text {-lag2 }}$ & 82.3 & 2179.8 & 86.1 & 2273.1 \\
\hline
\end{tabular}

Ekman transport and the longitudinal wind stress (proportional to $\mathrm{Q}_{\mathrm{T}}$ ) can be invoked to interpret the effect of $-Q_{L}$ on the settlement patterns.

With regard to the instantaneous effect of $-\mathrm{Q}_{\mathrm{L}}\left(-\mathrm{Q}_{\mathrm{L}-\mathrm{lag} 0}\right)$ on settlement abundance, the inclusion of this variable increased the variability explained to $82.3 \%$ and $83.3 \%$ of the total variance at Arnela and Miranda, respectively (Tables 5 \& $6)$. The model showed a similar seasonal pattern at both locations (Fig. 6A,B) but $-\mathrm{Q}_{\mathrm{L}-\mathrm{lag} 0}$ showed opposite effects on settlement abundance at Arnela and Miranda (Fig. 6C,D). At Arnela, - $\mathrm{Q}_{\mathrm{L}-\mathrm{lag} 0}$ showed an effect on settlement abundance for values above $0.5 \mathrm{~m}^{2}$ $\mathrm{s}^{-1}$. Above that threshold value, offshore transport $\left(-\mathrm{Q}_{\mathrm{L}-\mathrm{lag} 0}\right)$ showed an inverse relationship with settlement abundance (Fig. 6C). At Miranda, onshore transport $\left(-\mathrm{Q}_{\mathrm{L}-\text { lag0 }}<0\right)$ showed a detrimental effect on settlement magnitude. But when $-Q_{\mathrm{L}-\text { lago }}$ reached values around $0 \mathrm{~m}^{2} \mathrm{~s}^{-1}$, increments in its magnitude did not show an effect on settlement abundance (Fig. 6D). In addition, pvalues revealed a larger effect of $-\mathrm{Q}_{\mathrm{L} \text {-lag0 }}$ at Miranda (Table 6). indicated above, this similarity can be explained by the parallel time course of the longitudinal and transversal components of the wind (Fig. 2A). The inclusion of both variables simultaneously in the models increased the BIC values in all cases (Table 5) so models including just the longitudinal component $\left(-\mathrm{Q}_{\mathrm{L}}\right)$ were selected because the BIC value slightly decreased in most of the simulations (Table 5). In any case, both the longitudinal
Table 6. Structure of the models selected to describe settlement abundance in Arnela and Miranda locations according to instantaneous (lag 0 ) and time-lagged (lag 1 and lag 2) effects of $-Q_{\mathrm{L}}$. edf: estimated degrees of freedom. dev. expl. = deviance explained

\begin{tabular}{|c|c|c|c|c|c|c|c|c|c|c|c|}
\hline \multirow{2}{*}{$\begin{array}{l}\text { Lag } \\
\text { and site }\end{array}$} & \multicolumn{5}{|c|}{ - Parametric coefficients } & \multicolumn{4}{|c|}{ _ Smooth terms (non-parametric) _ـ } & \multirow{2}{*}{$\begin{array}{l}\mathrm{R}^{2} \\
\mathrm{adj}\end{array}$} & \multirow{2}{*}{$\begin{array}{r}\% \text { dev. } \\
\text { expl. }\end{array}$} \\
\hline & Parameter & Estimate & SE & Z & $\mathrm{p}$ & Parameter & edf & $\chi^{2}$ & $\mathrm{p}$ & & \\
\hline \multicolumn{12}{|l|}{ Lag 0} \\
\hline \multirow[t]{2}{*}{ Arnela } & Intercept & 3.914 & 0.068 & 57.782 & $<2 \times 10^{-16}$ & Date & 9.774 & 984.2 & $<2 \times 10^{-16}$ & 0.736 & 82.3 \\
\hline & Depth $6 \mathrm{~m}$ & -0.341 & 0.099 & -3.453 & $5.5 \times 10^{-4}$ & $-\mathrm{Q}_{\mathrm{L}-\mathrm{lag} 0}$ & 3.173 & 13.7 & $6.4 \times 10^{-3}$ & & \\
\hline \multirow[t]{2}{*}{ Miranda } & Intercept & 4.356 & 0.064 & 68.21 & $<2 \times 10^{-16}$ & Date & 8.813 & 1125.5 & $<2 \times 10^{-16}$ & 0.592 & 83.3 \\
\hline & Depth $6 \mathrm{~m}$ & -0.621 & 0.093 & -6.70 & $2.0 \times 10^{-11}$ & $-\mathrm{Q}_{\mathrm{L}-\operatorname{lag} 0}$ & 2.2023 & 16.0 & $6.4 \times 10^{-4}$ & & \\
\hline \multicolumn{12}{|l|}{ Lag 1} \\
\hline \multirow[t]{2}{*}{ Arnela } & Intercept & 3.766 & 0.054 & 69.869 & $<2 \times 10^{-16}$ & Date & 8.952 & 1225.5 & $<2 \times 10^{-16}$ & 0.827 & 89.4 \\
\hline & Depth 6 m & -0.315 & 0.076 & -4.147 & $3.4 \times 10^{-5}$ & $-\mathrm{Q}_{\mathrm{L}-\operatorname{lag} 1}$ & 11.888 & 179.2 & $<2 \times 10^{-16}$ & & \\
\hline \multirow[t]{2}{*}{ Miranda } & Intercept & 4.196 & 0.046 & 91.73 & $<2 \times 10^{-16}$ & Date & 13.400 & 1568.7 & $<2 \times 10^{-16}$ & 0.75 & 93.2 \\
\hline & Depth $6 \mathrm{~m}$ & -0.572 & 0.062 & -9.22 & $<2 \times 10^{-16}$ & $-\mathrm{Q}_{\mathrm{L}-\mathrm{lag} 1}$ & 16.610 & 262.8 & $<2 \times 10^{-16}$ & & \\
\hline \multirow[t]{2}{*}{ Arnela } & Intercept & 3.912 & 0.069 & 56.890 & $<2 \times 10^{-16}$ & Date & 8.886 & 870.6 & $<2 \times 10^{-16}$ & 0.664 & 81.8 \\
\hline & Depth $6 \mathrm{~m}$ & -0.330 & 0.100 & -3.289 & 0.001 & $-\mathrm{Q}_{\mathrm{L}-\mathrm{lag} 0}$ & 1 & 8.3 & 0.004 & & \\
\hline \multirow[t]{2}{*}{ Miranda } & Intercept & 4.325 & 0.060 & 72.06 & $<2 \times 10^{-16}$ & Date & 9.557 & 1142.8 & $<2 \times 10^{-16}$ & 0.604 & 86.2 \\
\hline & Depth $6 \mathrm{~m}$ & -0.635 & 0.086 & -7.349 & $1.99 \times 10^{-13}$ & $-\mathrm{Q}_{\mathrm{L}-\mathrm{lag} 0}$ & 0.969 & 59.5 & $1.2 \times 10^{-14}$ & & \\
\hline
\end{tabular}



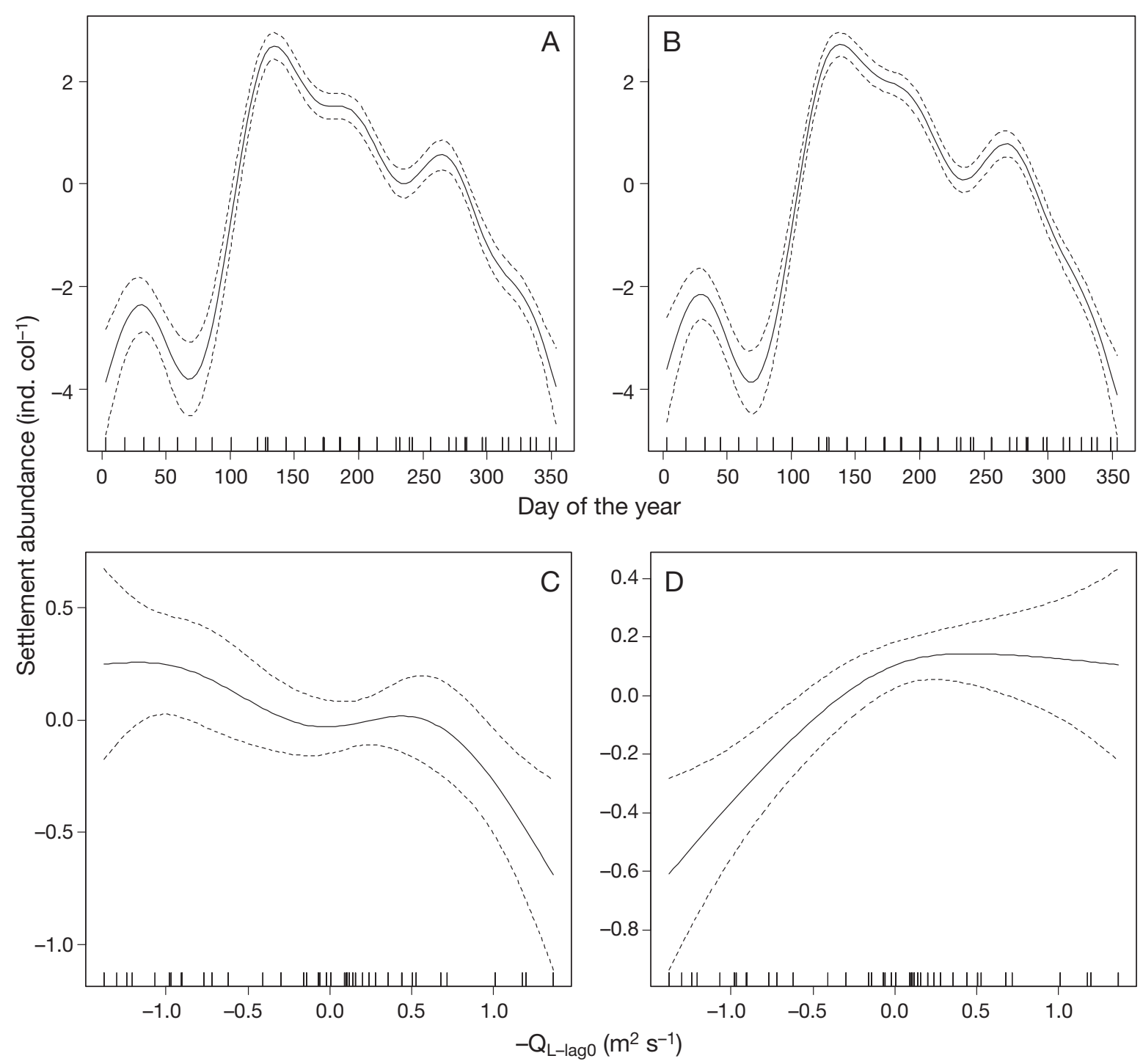

Fig. 6. Generalized additive models, showing the partial effects on settlement abundance of variables $(A, B)$ 'day of the year' and $(C, D)$ instantaneous longitudinal transport to the main axis of the ría $-Q_{L-l a g 0}\left(\mathrm{~m}^{2} \mathrm{~s}^{-1}\right)$ in $(A, C)$ Arnela and $(B, D)$ Miranda locations. Dashed lines show 95\% CI, and tick marks along the $x$-axis below each curve represent the values of the effect where observations occurred

According to the percentage of the total variability explained and the BIC values, the models that best describe settlement patterns in both locations included the average $-\mathrm{Q}_{\mathrm{L}}$ during the $15 \mathrm{~d}$ previous to the deployment of the collectors $\left(-\mathrm{Q}_{\mathrm{L}-\text { lag1i }}\right.$ Table 5$)$. These models explained $89.4 \%$ and $93.2 \%$ of the total variance at Arnela and Miranda, respectively (Tables 5 \& 6 ). These models again showed a strong seasonal pattern which placed settlement during the upwellingfavourable season (Fig. 7A,B). In addition, maximum settlement abundances matched in both locations with values of $-\mathrm{Q}_{\mathrm{L}}$ around $0 \mathrm{~m}^{2} \mathrm{~s}^{-1}$ during the fortnight previous to the deployment of the collectors (Fig. $7 \mathrm{C}, \mathrm{D}$ ).
The models that included the longitudinal transport with a $30 \mathrm{~d}$ lag $\left(-\mathrm{Q}_{\mathrm{L}-\mathrm{lag} 2}\right)$ explained $81.8 \%$ and $86.2 \%$ of the total variance at Arnela and Miranda, respectively (Tables $5 \& 6$ ). Again the seasonal effect led to settlement within the upwelling-favourable season (Fig. 8A,B). Settlement abundance increased linearly (estimated $\mathrm{df} \sim 1$; Table 6 ) with $-\mathrm{Q}_{\mathrm{L}-\text { lag2 }}$ values in both locations (Fig. 8C,D), but p-values again showed a larger influence of $-\mathrm{Q}_{\mathrm{L}-\mathrm{lag} 2}$ at Miranda (Table 6).

Fig. 9 illustrates the differences between settlement time series observed and predicted at Arnela and Miranda using instantaneous or lagged response models. 


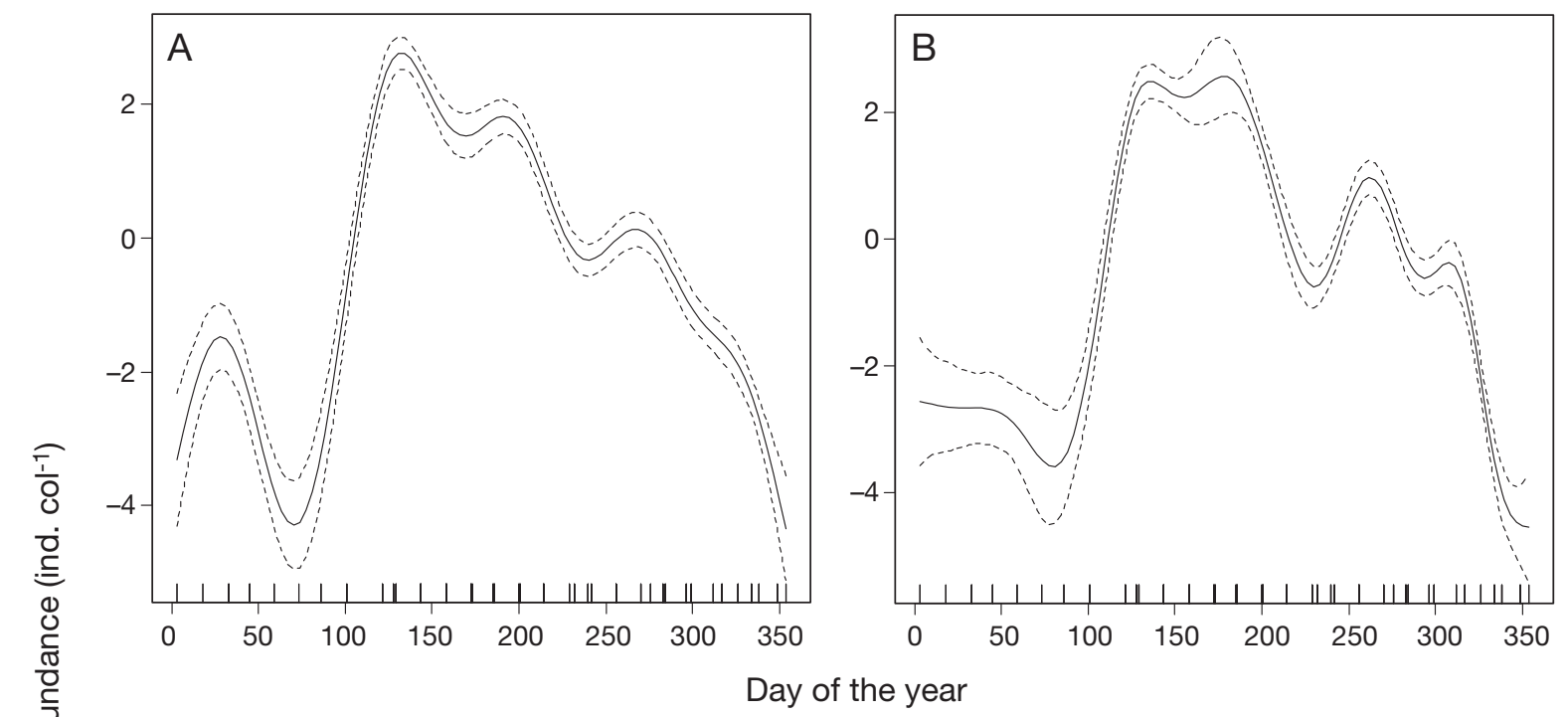

Day of the year

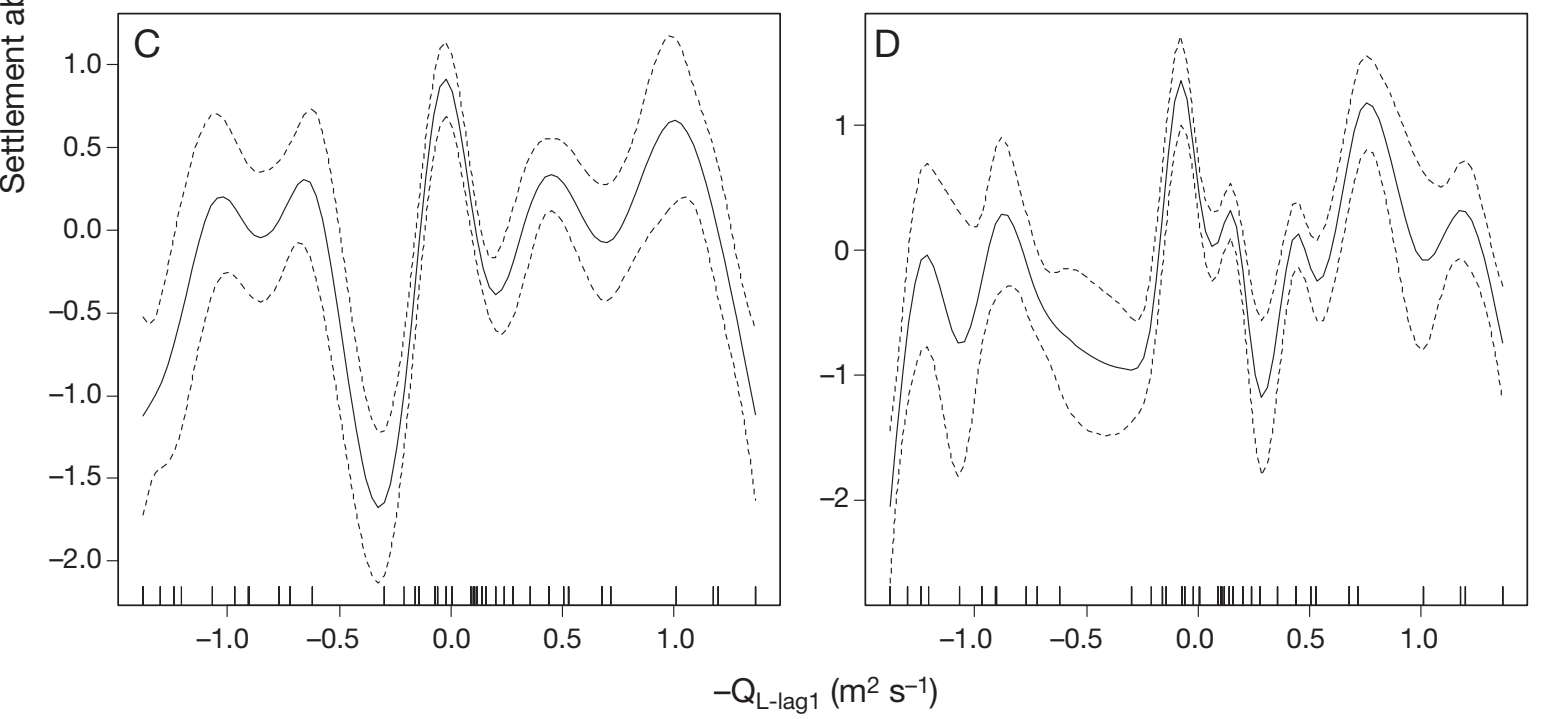

Fig. 7. General additive models showing the partial effects on settlement abundance of variables (A,B) 'day of the year' and $(\mathrm{C}, \mathrm{D}) 15 \mathrm{~d}$ lagged longitudinal transport to the main axis of the ría $-\mathrm{Q}_{\mathrm{L}-l a g 1}\left(\mathrm{~m}^{2} \mathrm{~s}^{-1}\right)$ in $(\mathrm{A}, \mathrm{C})$ Arnela and (B,D) Miranda locations. Dashed lines show 95\% CI, and tick marks along the $x$-axis below each curve represent the values of the effect where observations occurred

\section{DISCUSSION}

The time series of Mytilus galloprovincialis settlement in the Ría de Ares-Betanzos showed a strong seasonal pattern in both study years (Figs. 4 \& 5). Settlement was concentrated during the upwellingfavourable season (late spring to early autumn), which was characterized by the prevalence of northeasterly winds and a low river inflow (Figs. 2 \& 3). Seasonality alone can explain most of the variability recorded, not just in the presence of settlement (Table 1) but also in mussel abundance (Table 5).
Settlement abundance is characterized by an initial major peak followed by several peaks of decreasing magnitude (Figs. 6 to 8).

Temporal patterns characterized by several settlement peaks are usually related to either the synchronized spawning of gametes and subsequent simultaneous development, the occurrence of common transport episodes that cause a massive arrival of larvae to settlement locations, or a combination of both processes (Pineda 2000).

Mytilus galloprovincialis can release and fertilize gametes during the whole year at intermediate 

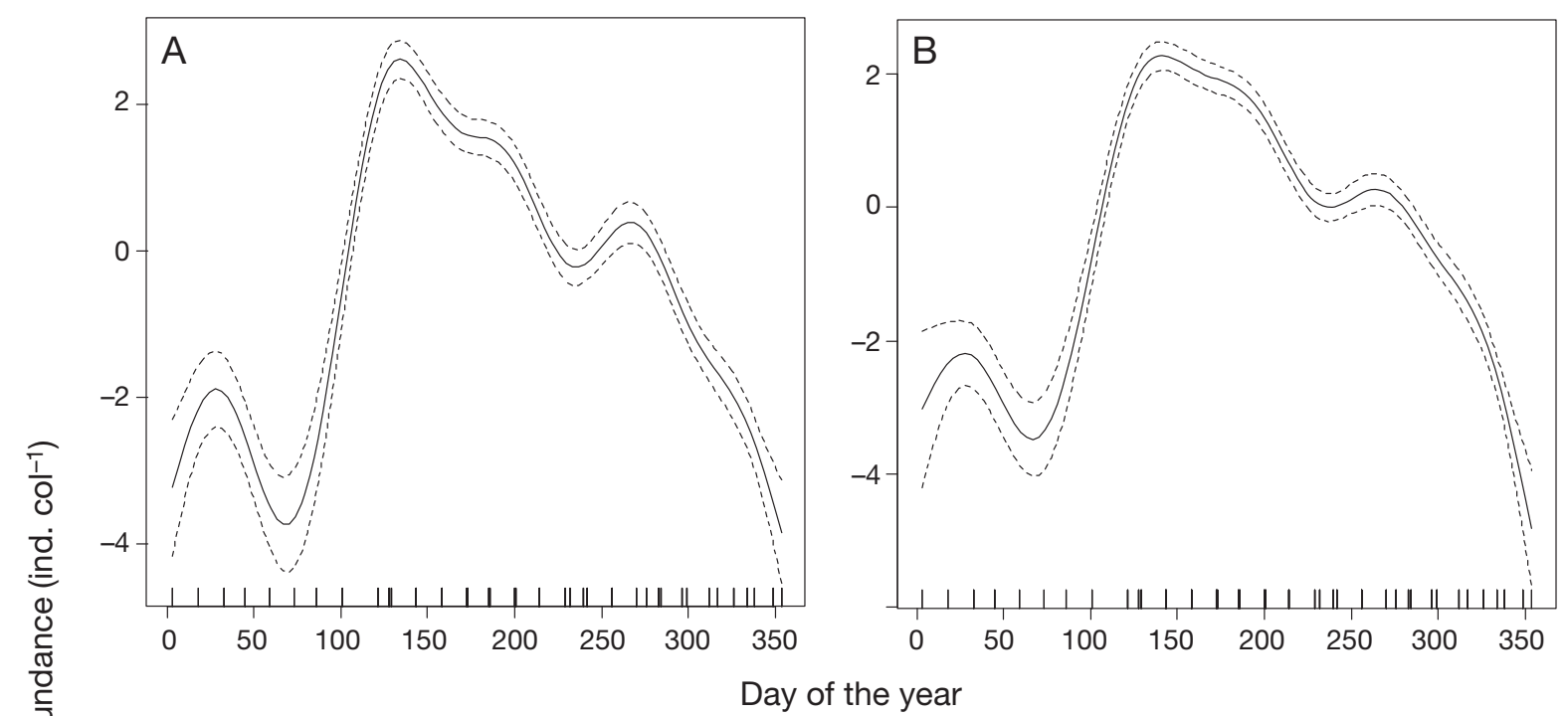

Day of the year

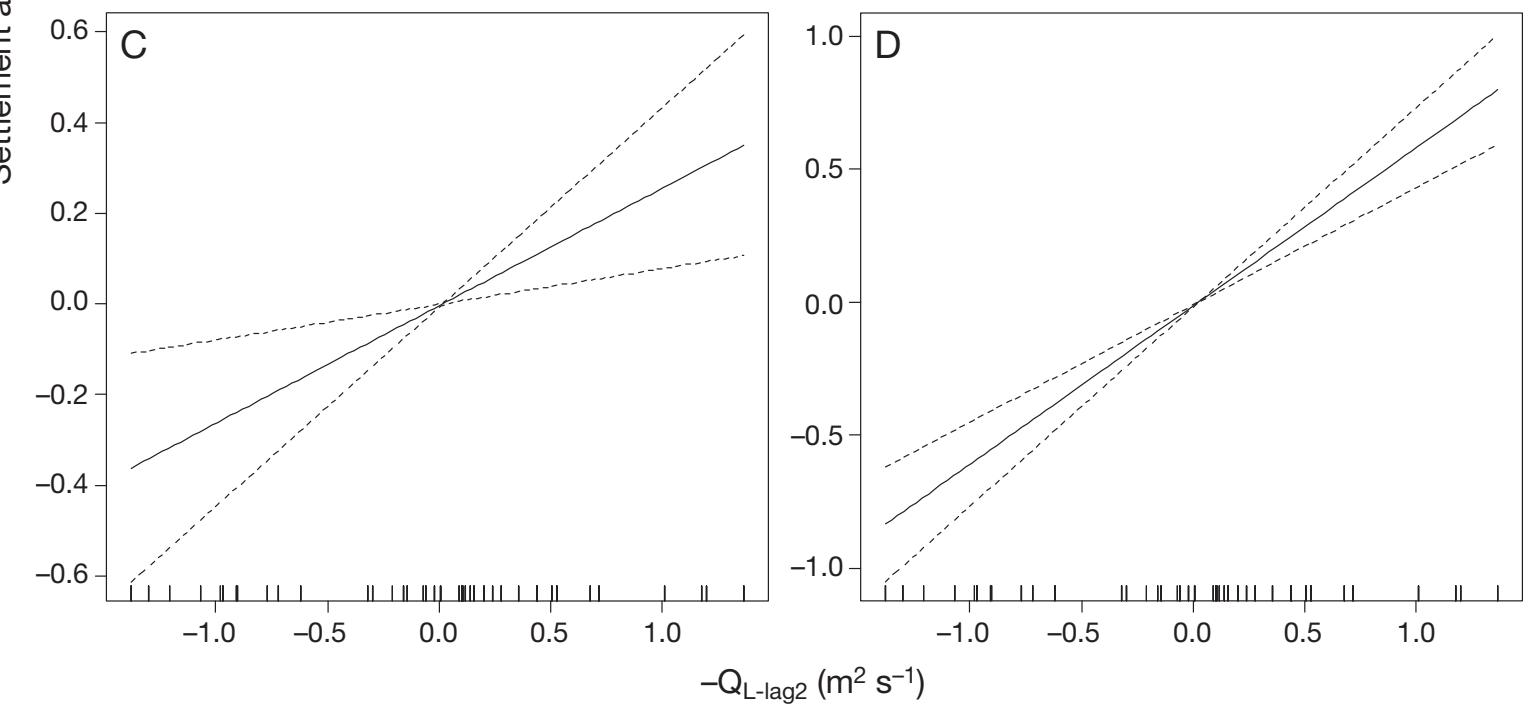

Fig. 8. General additive models showing the partial effects on settlement abundance of variables $(A, B)$ 'day of the year' and $(\mathrm{C}, \mathrm{D}) 30 \mathrm{~d}$ lagged longitudinal transport to the main axis of the ría $-\mathrm{Q}_{\mathrm{L}-l a g 2}\left(\mathrm{~m}^{2} \mathrm{~s}^{-1}\right)$ in $(\mathrm{A}, \mathrm{C})$ Arnela and $(\mathrm{B}, \mathrm{D}) \mathrm{Miranda}$ locations. Dotted lines show $95 \% \mathrm{CI}$, and tick marks along the $\mathrm{x}$-axis below each curve represent the values of the effect where observations occurred

latitudes, although massive spawnings are concentrated between early spring and summer (Snodden \& Roberts 1997, Cáceres-Martínez \& Figueras 1998b, Suárez et al. 2005). Although previous studies in the Ría de Ares-Betanzos described a single spawning event in mid-summer (Villalba 1995), our results showed the largest settlement densities in the spring. This pattern agrees best with the reproductive cycle described in the Southern Galician rías (Villalba 1995) and harmonizes larval development with the upwelling season.
Spawning in many invertebrate and fish species occurs primarily during the upwelling-favourable season suggesting some kind of advantage for larval development (Guisande et al. 2001, Shanks \& Eckert 2005, Otero et al. 2008, Morgan et al. 2009b, Otero et al. 2009). Although upwelling systems have been traditionally considered as dispersive environments (Roughgarden et al. 1988, Broitman et al. 2008), several studies have reported simple behaviours in different species of invertebrate larvae, for example the maintenance of a preferential depth, which allows for high larval retention close to parental habitats 

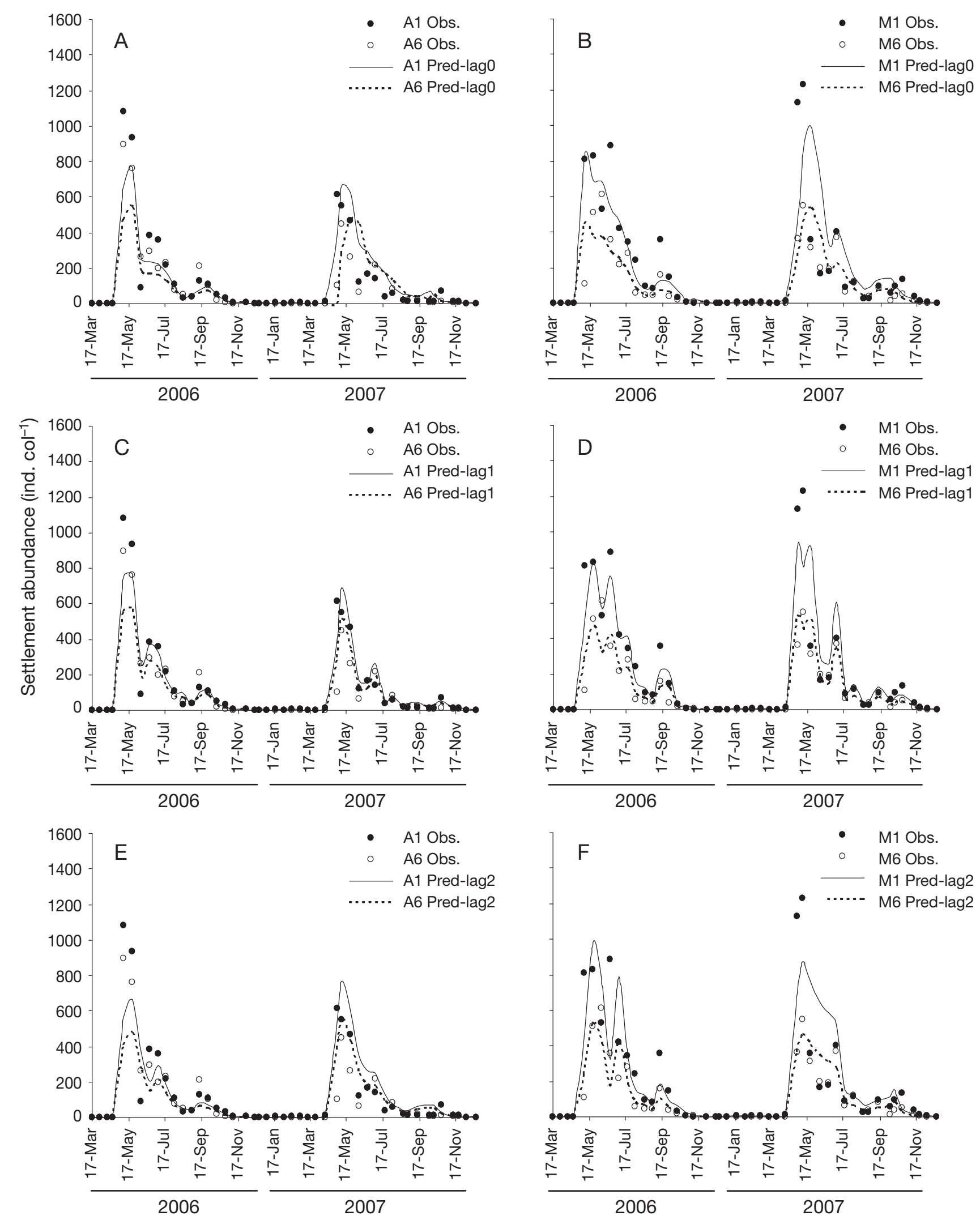

Fig. 9. Settlement time series observed and predicted at $(A, C, E)$ Arnela and $(B, D, F)$ Miranda using optimal models selected for $(\mathrm{A}, \mathrm{B})-\mathrm{Q}_{\mathrm{L}-\operatorname{lag} 0,}(\mathrm{C}, \mathrm{D})-\mathrm{Q}_{\mathrm{L}-\mathrm{lag} 1}$ and $(\mathrm{E}, \mathrm{F})-\mathrm{Q}_{\mathrm{L}-\mathrm{lag} 2}$. ind. col. ${ }^{-1}=$ individuals per collector 
(Sponaugle et al. 2002, Shanks \& Brink 2005, Morgan et al. 2009b). In the present study, preferential settlement of Mytilus galloprovincialis at $1 \mathrm{~m}$ depth was observed (Tables 1, 3, 4 \& 6), which suggests a higher concentration of competent larvae at the surface. Several studies have shown a highly variable vertical distribution for bivalves, which is species-specific (Shanks \& Brink 2005) and dependent on the larval developmental stage (Dobretsov \& Miron 2001, Morgan \& Fisher 2010). The differences among studies regarding the vertical distribution of mussel larvae in the water column (Dobretsov \& Miron 2001, Alfaro \& Jeffs 2002, McQuaid \& Phillips 2000, Morgan et al. 2009a) might be related to the dependence between vertical position and physical or biological discontinuities in the water column (Metaxas 2001, Shanks et al. 2003), as well as to the local topographic and hydrodynamic characteristics of each study area. Although in the present study settlement at $1 \mathrm{~m}$ was more probable and abundant at both locations, we also observed a greater difference in settlement magnitude between depths at Miranda (Tables 3, 4 \& 6). The topography and shallowness of Arnela (Fig. 1) may favour the action of local wind-stress from the surface to the bottom, allowing for a more homogeneous larval distribution in the water column in spite of significantly higher concentrations at the surface.

From a dispersive point of view, preferential depth at the surface may facilitate the onshore transport by different transport mechanisms like onshore coastal winds, sea breeze or internal waves (Shanks 1995). Larval concentration at the surface would also favour larval displacement to the shelf during active upwelling events and return to the coast during the subsequent upwelling relaxation or downwelling episodes (Roughgarden et al. 1988). Villegas-Ríos et al. (2011) suggested that the subtidal circulation in the inner part of the Ría de Ares-Betanzos is positive independently of the coastal winds, but they reported an increase in average flushing time during downwelling events with regard to upwelling episodes. A reversal of the circulation might occur in the outer part of the Ría de Ares-Betanzos in response to southwesterly coastal winds, as has been suggested for other Galician rías (Álvarez-Salgado et al. 2000, Piedracoba et al. 2005). Settlement delays detected in Miranda at $6 \mathrm{~m}$ depth might support the presence of reversed circulation events only in the outer ría. Although continental runoff may be a factor modulating flushing times and subtidal circulation in the Ría de Ares-Betanzos (Álvarez-Salgado et al. 2011, Villegas-Ríos et al. 2011), no significant effect of this variable on settlement was detected in the present study. Nevertheless, the regression models obtained showed that $-\mathrm{Q}_{\mathrm{L}}$ had a significant instantaneous and also delayed effect on the settlement magnitude of Mytilus galloprovincialis (Tables $5 \& 6$ ). The parallel time course of the longitudinal and transversal components of the coastal winds does not allow us to isolate the effect of the longitudinal Ekman transport (caused by transversal shelf winds) from the effect of the longitudinal wind stress (caused by longitudinal shelf winds). Therefore, $-\mathrm{Q}_{\mathrm{L}}$ should be interpreted as a proxy for regional scale circulation conditions.

Upwelling at our latitudes consists of a succession of moderate to intense wind stress and relaxation cycles occurring every 10 to $20 \mathrm{~d}$ (Álvarez-Salgado et al. 1993). This high frequency of upwelling episodes might constrain our capacity to relate a specific event with a settlement pulse because of the fortnightly sampling frequency of settlement densities.

With regard to the instantaneous effect of $-\mathrm{Q}_{\mathrm{L}}\left(-\mathrm{Q}_{\mathrm{L}}\right.$ lago) an inverse result on settlement magnitude was observed at the inner (Arnela) and outer (Miranda) locations (Fig. 6C,D). Intense offshore transport during the sampling interval, due to both longitudinal wind stress and Ekman transport, showed a detrimental effect on settlement magnitude at Arnela (Fig. 6C). On the contrary, settlement abundance decreased at Miranda when onshore transport prevailed (Fig. 6D). Prevalence of onshore transport enhanced the settlement at the inner part of the ría (Arnela) and reduced it at the outer part (Miranda), suggesting that larvae are mainly delivered from the inside of the ría. This pattern is consistent with the spatial distribution of reproductive adults, which are concentrated on the southern shore of the Ría de Ares-Betanzos (107 mussel rafts in Lorbé and 40 in Arnela; Fig. 1). Differences in the relevance of $-\mathrm{Q}_{\mathrm{L}-\text { lag0 } 0}$ on settlement between locations (p-values; Table 6) would support the hypothesis that differential larval supply is determined by differential wind forcing between the outer (Miranda) and inner (Arnela) ría. Since Miranda is located in the outer ría, its hydrodynamics might be more influenced by shelf wind stress and the coastal upwelling-downwelling regime, as reported in other Galician rías (Álvarez-Salgado et al. 2000, Piedracoba et al. 2005).

Although the regression model that includes $-\mathrm{Q}_{\mathrm{L}-\mathrm{lag} 0}$ helps to understand differences in settlement patterns between locations, the model that best describes settlement abundances in the ría included the average $-\mathrm{Q}_{\mathrm{L}}$ during the $15 \mathrm{~d}$ previous to the deployment of the collectors $\left(-\mathrm{Q}_{\mathrm{L}-\text { lag1 } 1}\right)$. Settlement magnitude at both locations showed an optimum for $-\mathrm{Q}_{\mathrm{L}-\text { lag1 }}$ values around $0 \mathrm{~m}^{2} \mathrm{~s}^{-1}$ (Fig. $7 \mathrm{C}, \mathrm{D}$ ) and pointed out the importance of the intermittency of 
longitudinal transport on settlement abundance of Mytilus galloprovincialis. The succession of active upwelling (offshore transport) and relaxation (onshore transport) periods allows for an optimal balance between the supply of nutrients for phytoplankton, growth of plankton in general and coastal retention of primary production (Figueiras et al. 2002, Otero et al. 2008, Villegas-Ríos et al. 2011). The intermittence of these episodes might affect settlement patterns, both indirectly through feeding patterns determining larval development and survival, and directly by limiting larval dispersal through the modulation of residence times and bottom shelf inflow in the ría. In this way, the decrease observed in settlement magnitude in 2007 compared with 2006 (Tables 3 \& 4) might be related to the lower variability of $-\mathrm{Q}_{\mathrm{L}}$ during 2007 (Fig. 2A). Recent works pointed out the relevance of frequency and variability of upwelling episodes in recruitment dynamics of diverse invertebrate species (Guisande et al. 2001, Otero et al. 2008, 2009, Pfaff et al. 2011). In addition, several studies have shown lower recruitment rates in areas with persistent downwelling (Menge et al. 2003) or upwelling conditions (Navarrete et al. 2005, Broitman et al. 2008, Dudas et al. 2009b, Smith et al. 2009) compared to geographical areas characterized by intermittent upwelling.

In relation to the $30 \mathrm{~d}$ delayed effect of $-\mathrm{Q}_{\mathrm{L}}$ $\left(-\mathrm{Q}_{\mathrm{L}-\mathrm{lag} 2}\right)$ on settlement abundance, a direct relationship between both variables was observed (Fig. 8C,D). Increases in larval settlement associated with positive values of $-Q_{L}$ during early larval stages (30 to $45 \mathrm{~d}$ before settlement) suggest that offshore transport associated with upwelling events is not limiting the larval supply to the ría. Several studies have reported similar results (Morgan et al. 2009a, Shanks \& Shearman 2009, Morgan \& Fisher 2010) and also a positive relationship between settlement and upwelling intensity (Pfaff et al. 2011). Different strategies have been suggested to avoid advection during upwelling events (Queiroga \& Blanton 2004, Shanks \& Brink 2005, Morgan et al. 2009b, Shanks \& Shearman 2009). In addition several mechanisms other than downwelling episodes (i.e. local winds, sea breeze, internal waves) have been described as effective for returning larvae to the coast (Shanks 1995). Although, the relationship between $-Q_{L-l a g 2}$ intensity and settlement is more relevant at Miranda (p-values; Table 6), the same pattern was observed at the inner location (Arnela), less influenced by shelf winds. This suggests an indirect relationship between $-\mathrm{Q}_{\mathrm{L}-\text { lag2 }}$ and settlement abundance. The prevalence of upwelling favourable winds could develop a front across the mouth of the bay which might contribute to larval retention into the estuary, as has been previously observed in different estuaries (McCulloch \& Shanks 2003). The positive relationship at both locations would also suggest that the preponderance of upwelling episodes during the early larval stages (30 to $45 \mathrm{~d}$ before settlement) enhances their survival because of food availability. Almost $100 \%$ of the limiting nutrients are provided to the Ría de Ares-Betanzos by shelf bottom waters during upwelling events, enhancing the net ecosystem production between 5 and 7 times in comparison to downwelling episodes (Villegas-Ríos et al. 2011). The increase in larval survival/settlement might be related to the fertilization of coastal waters during the upwelling season, which enhances primary and secondary production in the system (Guisande et al. 2001, Otero et al. 2008).

Changes detected in the coastal wind regime off the NW Iberian Peninsula during the last 40 yr indicate a reduction of $30 \%$ in the duration of the upwelling-favourable period and a $45 \%$ reduction in its intensity (Álvarez-Salgado et al. 2008). Based on the results of the present study, these changes in the wind regime could have a direct influence on the settlement of Mytilus galloprovincialis, as has been suggested for other commercial species with life cycles adapted to the seasonality of coastal upwelling in the NW Iberian Peninsula (Sardina pilchardus: Guisande et al. 2001; Octopus vulgaris: Otero et al. 2008, 2009).

In summary, the results of the present work illustrate the link between mussel settlement and the northeasterly winds prevalent during the upwelling favourable season. The positive effect of coastal upwelling events during the early planktonic life $\left(-\mathrm{Q}_{\mathrm{L}-\mathrm{lag} 2}\right)$ suggests a relevant role of coastal water fertilization for larval survival. The relevance of intermittent offshore transport/upwelling episodes during larval development ( $\left.-\mathrm{Q}_{\mathrm{L}-\mathrm{lag} 1}\right)$ seems to be related to the equilibrium provided between food supply and larval retention in the ría. At the end of larval development, longitudinal transport $\left(-\mathrm{Q}_{\mathrm{L}-\mathrm{lag} 0}\right)$ showed certain effects on the regulation of transport and meta-population connectivity, modulated by local hydrography and larval behaviour. The increasing evidence of many invertebrate species with life cycles highly adapted to coastal upwelling (Cury \& Roy 1989, Guisande et al. 2001, Shanks \& Eckert 2005, Otero et al. 2008, Morgan et al. 2009b, Shanks \& Shearman 2009, Pfaff et al. 2011) highlights the need for understanding ecosystem responses to changing environmental conditions and developing effective management and conservation strategies. 
Acknowledgements. We thank the mussel farm PROINSA and their employees, especially H. Regueiro, M. Garcia, C. Brea and O. Fernandez-Rosende for technical assistance. We are grateful to I. Fuentes for statistical advice and to 5 anonymous reviewers for their helpful comments and suggestions. This study was supported by the contract-project PROINSA Mussel Farm, codes CSIC 20061089 \& 0704101100001, and Xunta de Galicia PGDIT06RMA018E \& PGIDIT09MMA038E. Additional support came from the Ecological Sustainability Suspended Mussel Aquaculture (ESSMA) project Spain-Canada Grant of Ministerio de Ciencia e Innovación and Department of Fisheries and Oceans.

\section{LITERATURE CITED}

Alfaro AC, Jeffs AG (2002) Small-scale mussel settlement patterns within morphologically distinct substrata at Ninety Mile Beach, Northern New Zealand. Malacologia 44:1-15

Álvarez-Salgado XA, Rosón G, Pérez FF, Pazos Y (1993) Hydrographic variability of the Rías Baixas (NW Spain) during the upwelling season. J Geophys Res 98:1444714455

Álvarez-Salgado XA, Gago J, Miguez BM, Gilcoto M, Pérez FF (2000) Surface waters of the NW Iberian margin: Upwelling on the shelf versus outwelling of upwelled waters from the Rias Baixas. Estuar Coast Shelf Sci 51: 821-837

Álvarez-Salgado XA, Labarta U, Fernández-Reiriz MJ, Figueiras FG and others (2008) Renewal time and the impact of harmful algal blooms on the extensive mussel raft culture of the Iberian coastal upwelling system (SW Europe). Harmful Algae 7:849-855

> Álvarez-Salgado XA, Figueiras FG, Fernández-Reiriz MJ, Labarta U, Peteiro L, Piedracoba S (2011) Control of lipophilic shellfish poisoning outbreaks by seasonal upwelling and continental runoff. Harmful Algae 10: 121-129

Arístegui J, Barton ED, Álvarez-Salgado XA, Santos AMP and others (2009) Sub-regional ecosystem variability in the Canary Current upwelling. Prog Oceanogr 83:33-48

Bakun A (1973) Coastal upwelling indices, west coast of North America, 1946-71. NOAA Tech Rep NMFS, SSRF671.

> Barry SC, Welsh AH (2002) Generalized additive models and zero inflated count data. Ecol Modell 157:179-188

Becker BJ, Levin LA, Fodrie FJ, McMillan PA (2007) Complex larval connectivity patterns among marine invertebrate populations. Proc Natl Acad Sci USA 104: 3267-3272

> Broitman BR, Blanchette CA, Menge BA, Lubchenco J and others (2008) Spatial and temporal patterns of invertebrate recruitment along the west coast of the United States. Ecol Monogr 78:403-421

Cáceres-Martínez J, Figueras A (1998a) Distribution and abundance of mussel (Mytilus galloprovincialis Lmk) larvae and post-larvae in the Ría de Vigo (NW Spain). J Exp Mar Biol Ecol 229:277-287

> Cáceres-Martínez J, Figueras A (1998b) Long-term survey on wild and cultured mussels (Mytilus galloprovincialis Lmk) reproductive cycles in the Ría de Vigo (NW Spain). Aquaculture 162:141-156

> Chia FS, Auckland-Nicks J, Young CM (1984) Locomotion of marine invertebrate larvae: a review. Can J Zool 62: 1205-1222

Connell JH (1985) The consequences of variation in initial settlement vs post-settlement mortality in rocky intertidal communities. J Exp Mar Biol Ecol 93:11-45

Cowen RK, Lwiza KMM, Sponaugle S, Paris CB, Olson DB (2000) Connectivity of marine populations: open or closed? Science 287:857-859

Cury P, Roy C (1989) Optimal environmental window and pelagic fish recruitment success in upwelling areas. Can J Fish Aquat Sci 46:670-680

Davies G (1974) A method for monitoring the spatfall of mussels (Mytilus edulis L.). J Cons Int Explor Mer 36: 27-34.

> Dobretsov SV, Miron G (2001) Larval and post-larval vertical distribution of the mussel Mytilus edulis in the White Sea. Mar Ecol Prog Ser 218:179-187

> Dudas SE, Rilov G, Tyburczy J, Menge BA (2009a) Linking larval abundance, onshore supply and settlement using instantaneous versus integrated methods. Mar Ecol Prog Ser 387:81-95

- Dudas SE, Grantham BA, Kirincich AR, Menge BA, Lubchenco J, Barth JA (2009b) Current reversals as determinants of intertidal recruitment on the central Oregon coast. ICES J Mar Sci 66:396-407

Eckman JE (1996) Closing the larval loop: linking larval ecology to the population dynamics of marine benthic invertebrates. J Exp Mar Biol Ecol 200:207-237

Farrell TM, Bracher D, Roughgarden J (1991) Cross-shelf transport causes recruitment to intertidal populations in central California. Limnol Oceanogr 36:279-288

Figueiras FG, Labarta U, Fernández-Reiriz MJ (2002) Coastal upwelling, primary production and mussel growth in the Rias Baixas of Galicia. Hydrobiologia 484: 121-131

Graham WM, Largier JL (1997) Upwelling shadows as nearshore retention sites: the example of northern Monterey Bay. Cont Shelf Res 17:509-532

Grantham BA, Eckert GL, Shanks AL (2003) Dispersal potential of marine invertebrates in diverse habitats. Ecol Appl 13:S108-S116

Guisan A, Edwards TC, Hastie T (2002) Generalized linear and generalized additive models in studies of species distributions: setting the scene. Ecol Model 157:89-100

> Guisande C, Cabanas JM, Vergara AR, Riveiro I (2001) Effect of climate on recruitment success of Atlantic Iberian sardine Sardina pilchardus. Mar Ecol Prog Ser 223: 243-250

Labarta U (2004) El mejillón, un paradigma bioeconómico. In: Labarta U, Fernández Reiriz MJ, Pérez Camacho A, Pérez Corbacho E (eds) Bateeiros, mar, mejillón. Una perspectiva bioeconómica. Editorial Galaxia, Santiago de Compostela, p 15-43

> Ladah LD, Tapia FJ, Pineda J, López M (2005) Spatially heterogeneous, synchronous settlement of Chthamalus spp. larvae in northern Baja California. Mar Ecol Prog Ser 302:177-185

Lavín A, Díaz del Río G, Cabanas JM, Casas G (1991) Afloramiento en el noroeste de la península Ibérica. Índices de afloramiento para el punto $43^{\circ} \mathrm{N} 11^{\circ} \mathrm{O}$ periodo 1966-1989. Inf Tec Inst Esp Oceanog no. 91. Instituto Español de Oceanografia, Madrid

Leslie HM, McLeod KL (2007) Confronting the challenges of implementing marine ecosystem-based management. 
Front Ecol Environ 5:540-548

Levin LA, Bridges TS (1995). Pattern and diversity in reproduction and development. In: McEdward L (ed) Ecology of marine invertebrate larvae. CRC, Boca Ratón, FL, p 1-48

Mace AJ, Morgan SG (2006) Larval accumulation in the lee of a small headland: implications for the design of marine reserves. Mar Ecol Prog Ser 318:19-29

Marta-Almeida M, Dubert J, Peliz A, Queiroga H (2006) Influence of vertical migration pattern on retention of crab larvae in a seasonal upwelling system. Mar Ecol Prog Ser 307:1-19

> McCulloch A, Shanks AL (2003) Topographically generated fronts, very nearshore oceanography and the distribution and settlement of mussel larvae and barnacle cyprids. J Plankton Res 25:1427-1439

> McQuaid CD, Phillips TE (2000) Limited wind-driven dispersal of intertidal mussel larvae: in situ evidence from plankton and the spread of the invasive species Mytilus galloprovincialis in South Africa. Mar Ecol Prog Ser 201: 211-220

Menge BA (1992) Community regulation: under what conditions are bottom-up factors important on rocky shores? Ecology 73:755-763

> Menge BA, Lubchenco J, Bracken MES, Chan F and others (2003) Coastal oceanography sets the peace of rocky intertidal community dynamics. Proc Natl Acad Sci USA 100:12229-12234

Metaxas A (2001) Behaviour in flow: Perspectives on the distribution and dispersion of meroplanktonic larvae in the water column. Can J Fish Aquat Sci 58:86-98

> Morgan SG, Fisher JL (2010) Larval behaviour regulates nearshore retention and offshore migration in an upwelling shadow and along the open coast. Mar Ecol Prog Ser 404:109-126

> Morgan SG, Fisher JL, Mace AJ (2009a) Larval recruitment in a region of strong, persistent upwelling and recruitment limitation. Mar Ecol Prog Ser 394:79-89

Morgan SG, Fisher JL, Miller SH, McAfee ST, Largier JL (2009b) Nearshore larval retention in a region of strong upwelling and recruitment limitation. Ecology 90: 3489-3502

> Narváez DA, Navarrete SA, Largier J, Vargas CA (2006) Onshore advection of warm water, larval invertebrate settlement, and relaxation of upwelling off central Chile. Mar Ecol Prog Ser 309:159-173

> Navarrete SA, Wieters EA, Broitman BR, Castilla JC (2005) Scales of benthic-pelagic coupling and the intensity of species interactions: From recruitment limitation to topdown control. Proc Natl Acad Sci USA 102:18046-18051

> Otero J, Álvarez-Salgado XA, González A, Miranda A and others (2008) Bottom-up control of common octopus Octopus vulgaris in the Galician upwelling system, northeast Atlantic Ocean. Mar Ecol Prog Ser 362: 181-192

> Otero J, Álvarez-Salgado XA, Gonzalez AF, Gilcoto M, Guerra A (2009) High-frequency coastal upwelling events influence Octopus vulgaris larval dynamics on the NW Iberian shelf. Mar Ecol Prog Ser 386:123-132

> Pan M, Graham JP, Cunningham CO, Hay SJ (2011) Spatiotemporal coupling/decoupling of planktonic larvae and benthic settlement in decapods in the Scottish east coast. Mar Biol 158:31-46

Pfaff MC, Branch GM, Wieters EA, Branch RA, Broitman B (2011) Upwelling intensity and wave exposure deter- mine recruitment of intertidal mussels and barnacles in the southern Benguela upwelling region. Mar Ecol Prog Ser 425:141-152

Piedracoba S, Álvarez-Sagado XA, Rosón G, Herrera JL (2005) Short time scale thermohaline variability and residual circulation in the central segment of the coastal upwelling system of the Ría de Vigo (NW Spain) during four contrasting periods. J Geophys Res 110:C03018. doi: 10.1029/2004JC002556

Pineda J (2000) Linking larval settlement to larval transport: assumptions, potentials and pitfalls. In: Fäber-Lorda L (ed) Oceanography of the Eastern Pacific. CICESE, Ensenada, Mexico

Pineda J, Reyns NB, Starczak VR (2009) Complexity and simplification in understanding recruitment in benthic populations. Popul Ecol 51:17-32

Pineda J, Porri F, Starczak V, Blythe J (2010) Causes of decoupling between larval supply and settlement and consequences for understanding recruitment and population connectivity. J Exp Mar Biol Ecol 392:9-21

Porri F, McQuaid CD, Radloff S (2006) Temporal scales of variation in settlement and recruitment of the mussel Perna perna (Linnaeus, 1758). J Exp Mar Biol Ecol 332: 178-187

Poulin E, Palma AT, Leiva G, Narváez D, Pacheco R, Navarrete SA, Castilla JC (2002) Avoiding offshore transport of competent larvae during upwelling events: The case of the gastropod Concholepas concholepas in Central Chile. Limnol Oceanogr 47:1248-1255

Pyper J, Peterman RM (1998) Comparison of methods to account for autocorrelation in correlation analyses of fish data. Can J Fish Aquat Sci 55:2127-2140

> Queiroga H, Blanton J (2004) Interactions between behaviour and physical forcing in the control of horizontal transport of decapod crustacean larvae. Adv Mar Biol 47: $107-214$

Queiroga H, Cruz T, dos Santos A, Dubert J and others (2007) Oceanographic and behavioural processes affecting invertebrate larval dispersal and supply in the western Iberia upwelling ecosystem. Mar Ecol Prog Ser 74: 174-191

R Development Core Team (2010) R: A language and environment for statistical computing. R Foundation for Statistical Computing. Vienna, Austria. www.R-project.org

> Roughgarden J, Gains SD, Possingham H (1988) Recruitment dynamics in complex life cycles. Science 241: 1460-1466

Sánchez-Mata A, Glémarec M, Mora J (1999) Physicochemical structure of the benthic environment of a Galicia Ría (Ría de Ares-Betanzos, north-west Spain). J Mar Biol Assoc U K 79:1-21

Shanks AL (1995) Mechanisms of cross-shelf dispersal of larval invertebrates and fishes. In: McEdward L (ed) Ecology of marine invertebrate larvae. CRC Press, Boca Raton, FL, p 323-367

Shanks AL, Brink L (2005) Upwelling, downwelling, and cross-shelf transport of bivalve larvae: test of a hypothesis. Mar Ecol Prog Ser 302:1-12

Shanks AL, Eckert GL (2005) Population persistence of California Current fishes and benthic crustaceans: a marine drift paradox. Ecol Monogr 75:505-524

Shanks AL, Shearman RK (2009) Paradigm lost? Cross-shelf distributions of intertidal invertebrate larvae are unaffected by upwelling or downwelling. Mar Ecol Prog Ser 385:189-204 
Shanks AL, Largier J, Brink L (2000) Demonstration of the onshore transport of larval invertebrates by the shoreward movement of an upwelling front. Limnol Oceanogr 45:230-236

Shanks AL, Largier J, Brubaker J (2003) The nearshore distribution of larval invertebrates during an upwelling event. J Plankton Res 25:645-667

Smith JR, Fong P, Ambrose RF (2009) Spatial patterns in recruitment of the mussel Mytilus californianus (Conrad) in southern California, USA, two regions with differing oceanographic conditions. J Sea Res 61: 165-173

Snodden LM, Roberts D (1997) Reproductive patterns and tidal effects on spat settlement of Mytilus edulis populations in Dundrum Bay, Northern Ireland. J Mar Biol Assoc U K 77:229-243

Sponaugle S, Cowen RK, Shanks A, Morgan SG and others (2002) Predicting self-recruitment in marine populations: biophysical correlates and mechanisms. Bull Mar Sci 70S:341-375

Strahler AN (1963). Physical geography. Wiley, New York

Suárez MP, Alvarez C, Molist P, San Juan F (2005) Particular aspects of gonadal cycle and seasonal distribution of gametogenic stages of Mytilus galloprovnincialis in the

Editorial responsibility: Steven Morgan,

Bodega Bay, California, USA estuary of Vigo. J Shellfish Res 24:531-540

- Villalba A (1995) Gametogenic cycle of cultured mussel, Mytilus galloprovicialis, in the bays of Galicia (N.W. Spain). Aquaculture 130:269-277

Villegas-Ríos D, Álvarez-Salgado XA, Piedracoba S, Rosón G, Labarta U, Fernández-Reiriz MJ (2011) Net ecosystem metabolism of a coastal embayment fertilised by upwelling and continental runoff. Cont Shelf Res 31: 400-413

Wing SR, Largier JL, Botsford LW, Quinn JF (1995) Settlement and transport of benthic invertebrates in an intermittent upwelling region. Limnol Oceanogr 40:316-329

Wood SN (2006) Generalized Additive Models: An introduction with R. CRC/Chapman-Hall, Boca Raton, FL

Wooster WS, Bakun A, McLain DR (1976) The seasonal upwelling cycle along the eastern boundary of the North Atlantic. J Mar Res 34:131-141

Young (1995) Behavior and locomotion during the dispersal phase of larval life. In: McEdward L (ed) Ecology of marine invertebrate larvae. CRC Press, Boca Raton, FL, p 249-278

Zuur AF, Ieno EI, Walker NJ, Saveliev AA, Smith GM (2009) Mixed effects models and extensions in Ecology with R. Springer Science, New York

Submitted: February 7, 2011; Accepted: October 1, 2011 Proofs received from author(s): December 12, 2011 